NBER WORKING PAPER SERIES

\title{
OFF THE CLIFF AND BACK? CREDIT CONDITIONS AND INTERNATIONAL TRADE DURING THE GLOBAL FINANCIAL CRISIS
}

\author{
Davin Chor \\ Kalina Manova \\ Working Paper 16174 \\ http://www.nber.org/papers/w16174
NATIONAL BUREAU OF ECONOMIC RESEARCH
1050 Massachusetts Avenue
Cambridge, MA 02138
July 2010

We thank the editor, Charles Engel, and two anonymous referees for their detailed comments. We also thank Jae Bin Anh, Pol Antrás, Bo Becker, Marco Bugamelli, Jeanne Gobat, Robert Hall, Dirk Jenter, Luc Laeven, Philippe Martin, Marc Melitz, Dennis Novy, Monika Piazessi, Heiwai Tang, Daniel Treer, and David Weinstein for insightful conversations, as well as audiences at the 2010 AEA meetings, the EITI conference (Keio University), the Institute of Southeast Asian Studies (Singapore), the CEGE Annual Conference (UC Davis), the NY Fed Conference on Global Dimensions of the Financial Crisis, the NBER-SLOAN Project on Market Institutions and Financial Market Risk, the NBER ITI winter 2010 meeting, the Asia Pacific Trade Seminars (Osaka), Harvard international lunch, University of New South Wales, Nanyang Technological University, and Singapore Management University. Carlo Antonio Cabrera, Vera Eidelman, Chan Li, Jun Jia Ng, Zhicheng Song, and Abiy Teshome provided excellent research assistance. This project was supported by a Stanford Vice Provost for Undergraduate Education Faculty Grant and SMU Office of Research Grant No. 09-C244-SMU-010. The views expressed herein are those of the authors and do not necessarily reflect the views of the National Bureau of Economic Research.

NBER working papers are circulated for discussion and comment purposes. They have not been peerreviewed or been subject to the review by the NBER Board of Directors that accompanies official NBER publications.

(C) 2010 by Davin Chor and Kalina Manova. All rights reserved. Short sections of text, not to exceed two paragraphs, may be quoted without explicit permission provided that full credit, including $\odot$ notice, is given to the source. 
Off the Cliff and Back? Credit Conditions and International Trade during the Global Financial

Crisis

Davin Chor and Kalina Manova

NBER Working Paper No. 16174

July 2010, Revised February 2011

JEL No. F10,F14,F42,G01,G20,G28

\begin{abstract}
We study the collapse of international trade flows during the global financial crisis using detailed data on monthly US imports. We show that credit conditions were an important channel through which the crisis affected trade volumes, by exploiting the variation in the cost of capital across countries and over time, as well as the variation in financial vulnerability across sectors. Countries with higher interbank rates and thus tighter credit markets exported less to the US during the peak of the crisis. This effect was especially pronounced in sectors that require extensive external financing, have limited access to trade credit, or have few collateralizable assets. Exports of financially vulnerable industries were thus more sensitive to the cost of external capital than exports of less vulnerable industries, and this sensitivity rose during the financial crisis. The quantitative implications of our estimates for trade volumes highlight the large real effects of financial crises and the potential gains from policy intervention.
\end{abstract}

Davin Chor

Singapore Management University

School of Economics

90 Stamford Rd

Singapore 178903

Singapore

davinchor@smu.edu.sg

Kalina Manova

Department of Economics

Stanford University

579 Serra Mall

Stanford, CA 94305

and NBER

manova@stanford.edu 


\section{Introduction and motivation}

The global financial crisis has had far-reaching repercussions on cross-border economic activity. After a sharp and sudden collapse in international trade in the last quarter of 2008 , world trade flows declined by about $12 \%$ in 2009 according to the WTO. This exceeded the estimated loss of $5.4 \%$ in world GDP during the same period. ${ }^{1}$ The contraction in exports was especially acute for small open economies, several of whom saw their trade volumes in the second half of 2008 fall by up to $30 \%$ year-on-year. This trade decline contributed to the spread of recessionary pressures to countries which had little direct exposure to the US subprime mortgage market where the crisis originated. For example, the popular press has provided anecdotal accounts of how manufacturing plants around the world scaled down production and employment in response to limited export opportunities. ${ }^{2}$

Two aspects of the global financial crisis are believed to be behind this large decline in international trade. On the producer side, the credit crunch at the height of the crisis resulted in a severe reduction in the availability of external finance, thus curtailing firms' production and export capacities. On the consumer side, the gloomy economic outlook led to a slowdown in global demand in general, and for imports in particular. The effects of these forces may very well have been amplified by disruptions to global production lines, and by inventory adjustments made by importing firms and distributors.

This paper is one of the first to establish the effect that credit conditions had on international trade during the recent global crisis. We examine the evolution of monthly US imports over the November 2006 to October 2009 period, and compare trade patterns before and during the crisis. ${ }^{3}$ We identify the impact of credit conditions by exploiting the variation in the cost of external capital across countries and over time, as well as the variation in financial vulnerability across sectors. We find that during the crisis period, countries with higher interbank rates and thus tighter credit availability exported less to the US, relative to countries where interbank rates were lower as a result of more aggressive monetary easing policies. These effects were especially pronounced in sectors that require extensive external financing, have limited access to buyer-supplier trade credit, or have few collateralizable assets. ${ }^{4}$ In other words, exports of financially vulnerable industries were more sensitive to the cost of external capital than exports of less vulnerable industries, and this sensitivity rose during the financial crisis. These results are robust to controlling for cross-country differences in initial income (GDP and GDP per capita) and factor

\footnotetext{
${ }^{1}$ Authors' own calculations, using GDP in current prices from the IMF's World Economic Outlook Database.

${ }^{2}$ See for example Schwartz (2009a,b) in The New York Times.

${ }^{3}$ Based on the developments in global financial markets described in Section 2, we date the crisis period from September 2008 (when credit conditions started unraveling in earnest) to August 2009 (one year after, when conditions had largely calmed down). We discuss the robustness of our results to alternative crisis period dates later below.

${ }^{4}$ We use the term "trade credit" to refer to transactions between a firm and its buyers or suppliers that involve the transfer of goods or services without an advance or immediate transfer of payment funds. On the other hand, we use the term "trade finance" to refer to formal borrowing by firms from banks or other financial institutions to facilitate international trade activities, such as export letters of credit or trade insurance.
} 
endowments, which themselves could influence trade patterns. Moreover, our findings suggest that credit conditions exerted a disproportionately disruptive effect on trade flows beyond their effect on domestic output, as they continue to hold when we control for countries' industrial production index.

Using our estimates, we infer how US imports would have evolved under two alternative scenarios: (1) credit conditions remained tight, with interbank rates fixed at their September 2008 peak levels throughout the crisis period; and (2) credit conditions eased considerably, with interbank rates dropping immediately after September 2008 to their low levels of August 2009. These projections provide rough upper and lower bounds for the crisis-induced damage to trade flows mediated through the credit channel. We conclude that the 2008-2009 crisis would have reduced US imports by $2.5 \%$ more and $5.5 \%$ less under these respective scenarios, based on specifications in which the effect of credit conditions is estimated off the within-country variation in interbank rates. Estimates from less restrictive specifications that use the full cross-country variation in the cost of capital indicate that these magnitudes could have been much larger. Moreover, credit conditions contributed to large and systematic differences in export performance across sectors at different levels of financial vulnerability. For example, US imports in the most external finance dependent sector would have dropped $13.4 \%$ more and $8.2 \%$ less than imports in the least dependent sector, under the respective scenarios. Overall, these estimates highlight the large impact of financial market disturbances on the real economy and the scope for policy intervention through the easing of the credit crunch.

Our findings constitute new evidence on the importance of credit and financing for export activities. Access to outside capital matters for both domestic production and exporting because firms often incur substantial upfront costs that cannot be funded out of internal cash flows or retained earnings. Exporting, however, is more reliant on external finance for three reasons. First, it is associated with additional upfront sunk and fixed outlays specific to international trade. These include learning about the profitability of export opportunities; making market-specific investments in capacity, product customization, and regulatory compliance; and setting up and maintaining foreign distribution networks. Some variable trade costs, such as shipping and duties, may also have to be incurred before export revenues are realized. Second, exporters' need for working capital is magnified by the fact that cross-border transactions on average take between 30-90 days longer to process than domestic sales. ${ }^{5}$ Finally, the added risk that is faced in exporting relative to domestic activities necessitates insurance for many international transactions.

These factors have led to a very active credit market for cross-border activities: Up to $90 \%$ of world trade reportedly depends on some form of trade finance or insurance, with the total size of this market estimated at about \$10-12 trillion in 2008 (Auboin 2009). Given these considerations, firms located in

\footnotetext{
${ }^{5}$ See Djankov et al. (2010) and the Doing Business dataset. It can take up to 30 days in some countries to secure passage of a shipment from the factory to the export dock, and a further 30 days between arrival at the import dock and delivery at the destination warehouse. This does not include the time in shipping transit.
} 
countries with cheaper bank credit should in principle be able to produce and export more. Our finding that economies with lower interbank rates systematically exported more to the US is thus a reflection of the liquidity constraints that exporting firms around the world faced during the height of the crisis.

While credit availability is generally important in all industries, our empirical strategy relies on the observation that some sectors are more dependent on the financial system than others for arguably largely technological reasons beyond the control of individual firms. The growth and finance literature has identified several such measurable dimensions that characterize a sector's financial vulnerability. First, production and exporting in some industries are associated with bigger capital expenditures that cannot be serviced internally, and such industries require more external finance (Rajan and Zingales 1998). Second, in some sectors, firms routinely receive more buyer-supplier trade credit which gives them an alternative to and thus potentially reduces their dependence on bank financing (Fisman and Love 2003). Finally, industries with more tangible assets such as plant, property and equipment enjoy easier access to outside capital because firms can pledge more collateral (Braun 2003, Claessens and Laeven 2003). This is incidentally consistent with anecdotal evidence that many of the firms reporting big losses in output and employment since September 2008 have been in computers and electronics (Sprint, Nokia, Texas Instruments, Philips, Microsoft, Sony, Ericsson), transportation and machinery (Caterpillar, Harley Davidson), and chemical manufacturing and pharmaceuticals (Pfizer). ${ }^{6}$ These sectors feature relatively high dependence on external finance, limited access to trade credit, and/or low levels of tangible assets respectively (see Appendix Table 2).

The central result in our paper is that exports in financially vulnerable sectors became particularly sensitive to the cost of credit at the height of the global crisis. This cannot simply be attributed to countries with cheaper external capital having a comparative advantage in financially dependent industries, since this would not explain the intensification of the effect during the crisis. Instead, we offer two potential explanations. First, the crisis period saw US import demand plummet as American households cut consumption spending and American producers scaled down their purchases of intermediate inputs. This reduced the export revenues and profitability of foreign firms selling to the US, making it more difficult for these exporters to raise the necessary funds for their US sales from lenders in their home country. Second, exporting firms can in practice also access trade financing in the destination market or rely on trade credit raised there by the importing party. The availability of such US-based trade financing would have fallen sharply as the crisis unfolded, potentially hampering export flows to the US. The uneven impact of the crisis across countries and sectors can therefore be attributed to the combined effects of tighter credit at home, sectors' varying degree of financial vulnerability, and depressed demand and/or tighter credit in the US. Using data on retail sales and business loans in the US, we find evidence

\footnotetext{
${ }^{6}$ See Healy (2009) and Rampell (2009) in The New York Times.
} 
that the sharp drop in US final demand was more decisive in explaining trade patterns during the crisis period than the decline in US loan supply.

The rest of the paper proceeds as follows. Section 2 reviews the related literature. Section 3 describes the collapse in trade flows during the crisis, while Section 4 discusses the data used in our analysis. Section 5 presents our core results on the cross-country, cross-sector impact of credit conditions during the crisis period, while Section 6 examines their effects at the country level. We interpret the economic significance of our findings via the two hypothetical scenarios in Section 7. The last section concludes.

\section{Related literature}

Our results add to an established literature on the role of financial frictions in international trade. A number of theoretical and empirical papers have shown that, in the presence of credit constraints, countries with more developed financial institutions have a comparative advantage in financially vulnerable sectors. ${ }^{7}$ While this literature exploits the same cross-sector variation in financial vulnerability as we do, it typically relies on country-level measures of financial development (such as private credit over GDP, accounting standards, or creditor rights protection) that exhibit little or no time-series variation. By contrast, we explore the response of trade flows to short-term fluctuations in the cost of capital using high frequency (monthly) data. We also focus on export patterns before and during a financial crisis, instead of on conditions in steady state.

The global liquidity squeeze has renewed interest in academic and policy circles alike in the effect of credit constraints on export performance at the firm level. There is now ample evidence from micro data demonstrating that more credit-constrained firms indeed display a lower capacity for exporting. ${ }^{8}$ For example, Amiti and Weinstein (2009) show that Japanese banks transmitted financial shocks to exporters during the systemic crisis that plagued Japan in the 1990s. Similarly, Bricongne et al. (2010) find that the exports of French firms in more external finance-dependent sectors were more adversely hit during the recent global crisis.

Our paper also falls within a broader research agenda on the impact of banking and financial crises on economic outcomes such as sectoral growth (Kroszner et al. 2007, Dell'Ariccia et al. 2008) or firms' planned R\&D, employment, and capital spending (Campello et al. 2010). With regard specifically to the impact on international trade, Iacovone and Zavacka (2009) find that annual export growth rates were hurt more during banking crises in sectors more dependent on external finance and in sectors with

\footnotetext{
${ }^{7}$ See Kletzer and Bardhan (1987), Beck (2002), Matsuyama (2005), Becker and Greenberg (2007), Do and Levchenko (2007), Chaney (2005), Manova (2008a), and Ju and Wei (2008) for theoretical models, and Beck (2002, 2003), Svaleryd and Vlachos (2005), Hur et al. (2006), Becker and Greenberg (2007), and Manova (2008a,b) for empirical evidence.

${ }^{8}$ See for example Greenaway et al. (2007) based on UK data, Muûls (2008) on Belgium, Manova et al. (2009) on China, and Minetti and Zhu (2010) on Italy.
} 
fewer tangible assets, but that these effects were mitigated in countries with stronger levels of financial development. Our results further suggest that movements in the cost of capital can have large real effects on trade in the short run even when broader financial institutions remain unchanged.

Finally, our paper contributes to a fast-growing body of work investigating the trade effects of the 2008-2009 crisis. Freund (2009) and Levchenko et al. (2010) document that the decline in world trade has become increasingly pronounced relative to the decline in GDP in recent downturns, especially during the global financial crisis. ${ }^{9}$ Several papers have sought to explain this large fall in trade relative to output. Eaton et al. (2010) evaluate the relative contributions of changes in demand versus changes in trade frictions, using a general equilibrium model of production and trade. While they deduce that the fall in demand was more important, trade frictions nevertheless accounted for a significant fraction of the overall decline in the trade to GDP ratio. Behrens et al. (2010) reach a qualitatively similar conclusion, based on an analysis of Belgian firm-level data. ${ }^{10}$ Separately, Alessandria et al. (2010) explore the role of inventory adjustments, while Bems et al. (2010) and Levchenko et al. (2010) emphasize the disruption of global production lines and the reduction in trade in intermediate goods. There has also been work examining whether the decline in trade can be attributed to a rise in protectionist policies (Evenett 2009, Kee et al. 2010). We view these alternative mechanisms as potentially magnifying the role of credit conditions during the crisis, although we do not explicitly test this in the present paper.

\section{Preview: The crisis-related decline in US imports}

Our primary goal is to track how trade flows reacted to the unfolding global crisis. For this reason, we examine trade data on a monthly basis for the US. These data are readily available from the US Census Bureau website, and are regularly released with a lag of about three months.

Figure 1 offers an overview of the main trends in US aggregate trade over the sample period. Trade volumes were recording modest trend growth until mid-2008, when they started contracting severely both in terms of speed and magnitude. US trade flows witnessed a sharp month-on-month decline between October and November 2008, coinciding with the height of the global credit crunch. While nervousness over the exposure of financial institutions to the subprime mortgage market had been building up steadily since the end of 2007, two events in September 2008 - the collapse of Lehman Brothers and the government bailout of AIG - brought credit activity to a virtual standstill.

\section{[Figure 1 about here.]}

\footnotetext{
${ }^{9}$ See also Berman and Martin (2010) who detail the impact of the crisis on African countries' exporting prospects.

${ }^{10}$ The World Bank has similarly assessed that about $10-15 \%$ of the decline in international trade has been driven by the lack of trade financing, with the remaining decline attributable to the collapse in aggregate demand (reported in Auboin 2009), although these figures appear to be relatively rough estimates. See also McKibbin and Stoeckel (2009) who emphasize the much larger contraction of trade in durables relative to its production during the crisis.
} 
Several observations regarding the collapse in US trade flows are worth noting. First, the fall in US imports was more precipitous than that in US exports. On a month-on-month basis, US imports contracted 23.1\% between October and November 2008, while exports fell 13.6\%. This reflects presumably the particularly sharp decline in consumer sentiment and import demand in the US relative to other countries. ${ }^{11}$ Second, trade flows in the manufacturing sector (NAICS first digit $=3$ ) mirrored closely this aggregate decline. US manufacturing imports were 19.3\% lower in November 2008 compared with the previous month, while the corresponding fall for manufacturing exports was $13.8 \%{ }^{12}$ Third, this contraction was very broad-based, as reported in Table 1. Focusing on the import figures, no 3-digit manufacturing industry was spared, with the only difference across industries being one of severity. The worst-hit sector was by far petroleum and coal products where import volumes more than halved during this month. On the other end of the spectrum, food and furniture manufacturing saw the most moderate reductions, but these still registered a more than 5\% fall. Finally, although this is not shown in Figure 1, the drop in trade flows reflects primarily declines in quantities traded as opposed to prices, with one key exception: commodities and related industries (Levchenko et al. 2010, Haddad et al. 2010). Nevertheless, excluding the petroleum and coal sector does not change the overall picture of a sharp drop in trade flows.

[Table 1 about here.]

This collapse in US exports and imports coincided with a severe contraction in trade financing, a byproduct of the overall freeze in lending activity at the height of the crisis. While it is difficult to obtain definitive figures, estimates of the worldwide shortfall in trade finance range from $\$ 25-500$ billion for the second half of 2008 (Auboin 2009, Chauffour and Farole 2009). Separately, IMF reports have suggested that banks' capacity constraints affected about 6-10 percent of developing country trade, implying a trade finance gap in the order of $\$ 100-300$ billion (IMF-BAFT 2009).

In terms of the cost of trade financing, all available accounts point to sharply rising interest rates leading up to the last quarter of 2008. For example, an IMF-BAFT (Bankers' Association for Finance and Trade) survey of 44 banks from 23 developed and emerging markets reported a broad-based increase in the price of various trade-related credit instruments between October 2008 and January 2009. While the exact magnitudes vary across countries, there was a near doubling in the spread between banks' cost of funds and the rates on lines of credit or export credit insurance. A similar World Bank survey of firms and banks in 14 developing countries found that the crisis led to a fall in export pre-payments, forcing firms to stretch out their cash flow cycles. While the prices of different credit instruments apparently

\footnotetext{
${ }^{11}$ This contrast is even starker when the figures are calculated in year-on-year terms for November 2008: US imports fell $17.5 \%$, while US exports dropped a more moderate $4.9 \%$.

${ }^{12}$ Borchert and Mattoo (2009) document that trade in services was more resilient than trade in manufactured goods during the global financial crisis. They attribute this to the demand for services being less cyclical, and to services production and trade being less dependent on external finance.
} 
peaked and started to moderate by the first quarter of 2009, they were still above their pre-crisis levels (Malouche 2009). These developments prompted many economists and policy-makers to press the case for a coordinated push from country governments to shore up lines of credit (Ellingsen and Vlachos 2009), as evidenced by the April 2009 G20 Summit commitment to raise $\$ 250$ billion for trade finance.

\section{Data description}

Since our interest is in understanding how source-country differences in the severity of the credit crunch affected trade performance, we examine US import flows in what follows. We use monthly data for a three-year window, starting in November 2006. It is helpful to have the data start before 2007, as the problems in the US subprime mortgage market were already becoming apparent in the second half of 2007. Our sample ends in October 2009, amid signs of a steady recovery in trade flows (Figure 1). ${ }^{13}$

We require a measure of credit conditions across countries as our key explanatory variable. In principle, a direct measure of the cost of trade financing, such as the rates charged on export credit lines or insurance, would be ideal. Such data are unfortunately not readily available for a large sample of countries. For example, the IMF and World Bank surveys cited above suffer from limitations in country and time coverage, as well as potential difficulties in the cross-country comparability of the credit instruments for which rates are quoted.

In the absence of systematic information on trade financing costs, we appeal instead to a broader measure of the cost of external finance in the economy. We use the interbank lending rate as a measure of the tightness of prevailing credit conditions in each country over time. These interbank rates are the interest rates that commercial banks charge each other for short-term loans of a pre-set duration (typically: overnight, one month, or three months), which allow banks to adjust their liquidity positions and meet reserve requirements. More generally, the interbank rate has come to be seen as a benchmark for the overall cost of credit in the economy, as other loans such as housing mortgage rates often take their cue from it. During the recent crisis, the interbank rate was a closely-watched indicator that exhibited co-movements with the level of financial stress that the corporate sector was experiencing: Spikes in the interbank rate coincided with a drop in firms' ability to access external capital through the commercial paper market in North America and Europe, while the converse movements were observed as the crisis eased over time (Keogh 2008, Freilich and McGeever 2009, Brunnermeier 2009). ${ }^{14}$ To the extent that

\footnotetext{
${ }^{13}$ While the Census Bureau typically posts the trade data within 3 months, it periodically updates past data, presumably as more precise figures become available. Any such revisions are minor, typically not exceeding $1 \%$ of the trade value initially reported. We view this as part of the standard noise in our regression models.

${ }^{14}$ For our purposes, it would naturally be preferable to have a measure of the cost of borrowing such as commercial paper rates that reflects the default risk specific to firms, as opposed to that of banks. Such data are unfortunately not available for a wide set of countries, especially since commercial paper tends to be used as a primary means for firms to raise capital in North America and select European markets.
} 
the interbank rate is a noisy measure of the actual cost of trade financing to exporting firms, it would introduce measurement error and bias our estimation results downwards.

There are two further reasons why we may in fact underestimate the true impact of financial distress on trade flows by using the interbank borrowing rate. First, the lending terms we observe are for contracts that actually took place. Since financial transactions that did not occur would have presumably cleared at higher interest rates, the actual cost of capital for the marginal exporter would likely have been even higher. Second, survey and anecdotal evidence indicate that at the height of the crisis, credit tightening manifested itself in both higher costs of credit and limited availability of external financing, both of which would hamper firms' ability to export. We unfortunately cannot evaluate the impact of credit rationing, given the absence of systematic data on loan quantities across countries and over time. Our results using the interbank rate can thus be seen as providing a lower bound for the combined effect of both margins of credit tightening.

In practice, at any given time, interest rates may differ across individual interbank contracts, depending for example on the perceived credit-worthiness of the borrowing institution. That said, these rates have historically exhibited a high correlation across lending banks within a country, particularly in developed economies where the banking industry is competitive. In some countries, banking associations and even the central bank will quote a reference rate that reflects prevailing conditions in the interbank market, which then serves as a benchmark for the cost of borrowing in that economy. A well-known example is the London Interbank Offer Rate (LIBOR), which is reported each business day by the British Bankers' Association (BBA). Reflecting this reality, the Thomson Reuters Datastream database which we use can contain more than one interbank rate series for a country, even for loans of the same duration. For each country, we opted first to use a series quoted by the country's central bank. If this was not available, we then turned to rates reported by banking associations or regulatory bodies, such as the BBA, European Banking Federation (FBE), or Financial Markets Association (ACI). In the absence of such sources, we then chose finally to use an interbank rate quoted by a major commercial bank.

For our baseline results, we use the one-month (or thirty-day) interbank rate, to be consistent with the typical duration needed to complete an international trade shipment. Our results are extremely similar when we instead use the three-month (or ninety-day) rate, as the various rates are highly correlated. We average the interbank rate quoted across business days to obtain a monthly measure of the cost of credit in each country. In all, Datastream provides information on interbank rates for a sample of 31 economies. While this may not be a particularly large number of countries, it nevertheless covers most of the US' key trading partners and up to $72 \%$ of total US manufacturing imports in $2007 .{ }^{15}$ The sample also contains a broad spectrum of countries in terms of levels of economic and financial development,

\footnotetext{
${ }^{15}$ The three largest US trade partners by import value that are missing from our sample are Mexico, Israel, and Korea.
} 
including most of the OECD, several key emerging markets (Romania, Hungary) and some small open economies (Singapore, Hong Kong). We do not view the lack of coverage of developing countries as a major problem, as the interbank rate is likely a poorer indicator of the cost of credit in countries where the banking sector and interbank market are generally less developed.

Figure 2 and Appendix Table 1 illustrate the evolution of the one-month interbank rate during our sample period. Borrowing rates typically peaked in mid to late 2008 in most major economies. This reflects the rising cost of private credit as banks became extremely averse to lending and preferred instead to shore up their capital positions. Lending rates spiked in September 2008, when Lehman Brothers collapsed and AIG failed. Credit conditions only began easing in November 2008, in response to the broad range of extraordinary monetary policy moves deployed by central banks around the world to bolster liquidity. These successfully lowered the interbank cost of borrowing from a median in our sample of $4.66 \%$ (September 2008) to $0.44 \%$ (October 2009).

\section{[Figure 2 about here.]}

Beneath this broad trend, there are important differences in the time paths of the interbank rate across countries. This reflects differences in the severity and timing of the credit crunch, as well as the extent to which policy interventions were successful at easing credit conditions. In countries such as Germany and Bulgaria, the interbank rate was on a steady upward trend before an abrupt reversal in October and November 2008. In contrast, interbank rates were declining from a much earlier date in Canada and Singapore, where central bankers intervened earlier to cope with the impending downturn. In China, there was a spike in the cost of credit in the latter half of 2007, well before the height of the crisis in the US and Europe. As for Japan, although interbank rates there also crept up during the financial crisis and fell back again as monetary easing commenced in the last quarter of 2008, they were always very low and never climbed above the $1 \%$ level. This cross-country variation in the (policy-induced) declines in the cost of credit will be crucial to our empirical strategy for estimating the importance of credit conditions for international trade.

Our empirical strategy further exploits differences in the sensitivity to credit availability across sectors. We follow closely the prior literature in constructing three such variables of industry financial vulnerability. External finance dependence $(E X T F I N)$ is measured as the fraction of total capital expenditure not financed by internal cash flows from operations, and reflects firms' requirements for outside capital (Rajan and Zingales 1998). Access to (buyer-supplier) trade credit (TCRED) is calculated as the ratio of the change in accounts payable over the change in total assets, and indicates how much credit firms receive in lieu of having to make upfront or spot payments (Fisman and Love 2003). In principle, the availability of such trade credit provides a potential substitute to formal trade financing. Note that while EXTFIN proxies for firms' long-term needs for external finance, TCRED relates to 
their short-term working capital requirements. Finally, asset tangibility ( $T A N G)$ is constructed as the share of net plant, property and equipment in total book-value assets. This captures firms' ability to pledge collateral in securing external finance (Braun 2003, Claessens and Laeven 2003).

To construct each of these variables, we use data on all publicly-traded firms in Compustat North America. We first calculate financial vulnerability at the firm level as an average measure over the 1996-2005 period. This pre-dates the crisis, so that its impact on firm behavior does not contaminate the measures. We then use the median value across firms in each NAICS 3-digit category as the sector measure of EXTFIN, TCRED and TANG, respectively. Appendix Table 2 lists these values and provides some summary statistics for the 21 industries in our data.

These three variables are widely viewed as technologically-determined characteristics of a sector which are innate to the manufacturing process and exogenous from the perspective of an individual firm. This is corroborated by the relative stability of these measures over time and their much greater variation across industries than among firms within a given industry. The value of these sector characteristics may in principle differ across countries, but we construct them using US data. This is motivated by three considerations. First, similar firm-level data are not systematically available for a broad range of countries. Second, the US has one of the most advanced financial systems, recent developments notwithstanding, and the behavior of US firms thus likely reflects an optimal choice over external financing and asset structure. Finally, our empirical strategy requires only that the relative rank ordering of the industries remain stable across countries, even if the precise magnitudes may vary.

As is standard in the literature on trade and finance, the sector measures we use are based on firms' overall financing decisions and asset composition. While they are not available specifically for activities related to international trade, we argue that they are nevertheless appropriate proxies for three reasons, which we illustrate for the case of external finance dependence. First, firms need to incur the same production costs in manufacturing for the foreign market as in manufacturing for the home country, and these production costs often constitute a large share of the total cost of exporting. Second, products which entail a lot of $\mathrm{R} \& \mathrm{D}$, marketing research and distribution fixed costs at home plausibly also require similarly large fixed costs for product customization, marketing and distribution in foreign markets. Both of these factors imply that whatever forces a firm in a particular industry to fund its domestic operations with outside finance will also force it to use external capital for its sales abroad. Finally, the empirical measure is based on data for all publicly listed companies in the US. Since these companies are typically large exporters, EXTFIN measures their total requirement for external finance, and not just that for their domestic activities. Similar arguments can be made for the sector measures of trade credit intensity and asset tangibility. Ultimately, what is important for identifying the effects of credit conditions on trade flows is the relative rank ordering of sectors in terms of financial vulnerability. As long as this rank 
ordering is similar for domestic sales and exporting, the sector indicators we use will reflect it.

The Data Appendix describes all other control variables used in the empirical analysis.

\section{Effects of credit conditions across countries and sectors}

We examine how credit conditions affected trade flows during the global financial crisis in three steps. We first show that countries with higher interbank rates exported relatively less in financially vulnerable sectors, and that this effect intensified during the peak crisis months. Exploiting the variation across countries and sectors in this way allows us to isolate the effect of credit conditions from that of other potential confounding factors. Next, we document that at the country level, a higher interbank rate was indeed associated with lower exports to the US during the crisis period, but not in the months before or after it. Together, these two steps allow us to gauge the magnitude of the effect that credit conditions had on the level and sectoral composition of trade flows.

In this section, we undertake the first of these steps, and study the differential effect of the crisis across exporting countries with varying levels of credit tightness and across sectors with varying levels of financial vulnerability. We explore the three sector characteristics that reflect firms' sensitivity to the cost of external capital: dependence on external finance ( $E X T F I N)$, access to trade credit (TCRED), and endowment of tangible assets $(T A N G)$. Focusing on one sector measure at a time, for example EXTFIN, we estimate the following specification:

$$
\begin{gathered}
\ln Y_{i k t}=\beta_{1} \text { IBrate }_{i t} \times \text { EXTFIN }_{k}+\beta_{2} D_{\text {crisis }} \times \text { IBrate }_{i t} \times \text { EXTFIN }_{k} \\
+D_{i t}+D_{k t}+D_{i k}+\epsilon_{i k t}
\end{gathered}
$$

where $Y_{i k t}$ is the value of US imports from country $i$ in sector $k$, and IBrate $_{i t}$ is the interbank rate in that exporting country during month $t$. We report standard errors clustered by country, to allow for correlated idiosyncratic shocks at the exporter level. Similar results obtain under clustering at the country-industry level instead (available on request).

We define $D_{\text {crisis }}$ as a binary variable equal to 1 from September 2008 to August 2009, which we refer to as the crisis period. We date the start of this crisis period to a key month (September 2008) marked by several major financial institution failures and bailouts, including Lehman Brothers and AIG, that triggered a sharp escalation in the global credit crunch. On the other hand, trade flows were on a steady recovery path by the second half of 2009. We thus designate August 2009 as the last month for the crisis

dummy, one year after its onset. That said, our intention is not to provide a canonical dating for the end of the crisis; our results are similar if we allow the crisis dummy to stretch to the last month in our sample (October 2009). 
The main variables of interest are the double and triple interaction terms. The coefficient on IBrate $_{i t} \times E X T F I N_{k}$ estimates the effect of fluctuations in countries' cost of capital over time on the sectoral composition of their exports. We expect that countries may export relatively less in financially dependent sectors when they experience higher interbank rates, namely $\beta_{1}<0$. Given the extensive set of fixed effects used in the regression (see the discussion below), $\beta_{1}$ is identified from the variation in financial dependence across industries within a given country-month, the variation in the cost of credit across exporting countries in a given industry-month, and the variation in the cost of credit over time within a given country-sector.

The triple interaction term $\left(D_{\text {crisis }} \times\right.$ IBrate $\left._{i t} \times E X T F I N_{k}\right)$ in turn tests whether the sensitivity of financially vulnerable sectors to the cost of capital intensified during the crisis period. Equivalently, $\beta_{2}$ establishes whether any negative effect of the crisis on exports was not only stronger in countries with tighter credit markets, but also concentrated on the most financially dependent sectors in those countries. We thus anticipate that $\beta_{2}<0$. Conceptually, $\beta_{2}$ reports the difference between the crisis-driven change in exports of a country with tight credit markets in a financially dependent sector versus a financially less dependent sector, and compares that to the same difference for a country with lower interbank rates.

Importantly, we condition on an extensive set of fixed effects to guard against omitted variables bias. First, we include industry-month pair fixed effects, $D_{k t}$. Among other things, these control for fluctuations in sector-specific import demand in the US, for any time-series variation in the availability of trade financing in the US, and for monthly seasonality in the trade data. Note also that these fixed effects subsume the average effect of the crisis on US bilateral imports (the main effect of $D_{\text {crisis }}$ ), and any differential effect that the crisis had on sectors at different levels of financial dependence $\left(D_{\text {crisis }} \times\right.$ $\left.\operatorname{EXTFIN} N_{k}\right)^{16}$

We further control for country-month fixed effects, $D_{i t}$. These take into account the impact of shocks to aggregate production and credit conditions in each exporting country over time, as well as bilateral exchange rate fluctuations. They also accommodate the possibility that the financial crisis affected exports differentially across countries with varying degrees of credit tightness, which would have entered as $D_{\text {crisis }} \times$ IBrate $_{i t}$ had country-month fixed effects been excluded.

Finally, we incorporate country-industry fixed effects, $D_{i k}$. These account for time-invariant sources of comparative advantage that affect the average pattern of country exports across sectors. In particular, they control for the comparative advantage that countries with lower interbank rates might have in financially dependent sectors on average.

\footnotetext{
${ }^{16}$ If consumers also need to borrow, sectors' dependence on external capital on the consumption side may in principle be correlated with sectors' dependence on external capital on the production side. The $D_{k t}$ 's, however, control for US consumer demand by sector and month, including consumers' ability to finance such demand. The triple interaction thus isolates the trade effect of credit conditions on the production side, in the exporting country.
} 
It should be emphasized that this estimation approach provides a very stringent test. The set of fixed effects included is exhaustive in that only explanatory variables that simultaneously vary by country, industry and month can be estimated. This significantly allays concerns regarding omitted variables and alternative explanations. Consider, for instance, the possibility that the interbank rate might capture the effect of some other unobserved country characteristic which was the actual driving force behind the impact of the crisis on trade flows. This could rationalize why countries with higher interbank rates may have seen their export levels decline during the crisis (an effect implicitly controlled for with the countrymonth fixed effects). It could not, however, easily explain why the crisis exerted a disproportionately large effect on financially vulnerable industries in such countries.

\subsection{Core results}

The results from estimating equation (1) are presented in Table 2. As anticipated, we find that countries with higher interbank rates tend to export relatively less in sectors with a greater requirement for external finance $\left(\beta_{1}<0\right)$, although this is not precisely estimated (Column 1). Of note, this effect intensified significantly during the crisis period $\left(\beta_{2}<0\right.$, Column 2 , significant at the $10 \%$ level).

\section{[Table 2 about here.]}

We obtain similar results when considering the variation in sectors' access to trade credit (TCRED). On the one hand, trade credit that is extended by upstream suppliers or downstream buyers in lieu of cash in advance or spot payments can offer firms a substitute for formal bank loans. If one's business partners are willing and able to continue extending trade credit despite developments in the financial sector, this would suggest that industries with greater routine access to trade credit would be more resilient in the face of high costs of trade financing. On the other hand, it is possible that the willingness to extend trade credit may have dried up as a result of the general liquidity crunch. If so, trade credit may have diminished during the crisis period, with a more severe export contraction witnessed in countries with higher interbank rates, where both formal and informal credit would presumably have been hit harder.

The results in Columns 4 and 5 point strongly to the former interpretation. Countries with high interbank rates exported relatively more in sectors with greater access to trade credit, and this effect became more pronounced during the crisis period $\left(\beta_{2}>0\right.$, significant at the $1 \%$ level). This result is not inconsistent with the anecdotal evidence of a collapse in overall financing during the crisis for two reasons. First, our measure of TCRED is based on firms' use of trade credit in 1996-2005, before the crisis began. Second, and more importantly, our identification relies on the technologically-determined variation in this measure across sectors. Fisman and Love (2003) have shown that the relative ranking of sectors is similar when TCRED is computed using firm-level data from different decades. This suggests 
that the ranking of sectors by TCRED would likely remain stable even when the level of total trade credit available, and presumably that available in each sector, drops.

Finally, we consider sectors' endowment of tangible assets ( $T A N G)$ as an inverse proxy for financial vulnerability. Since industries characterized with more hard assets can in principle offer greater collateral to secure a loan, such sectors should be less sensitive to adverse credit conditions. We thus expect the signs of the coefficients to be reversed compared to the results obtained with EXTFIN. Indeed, we find that countries with higher interbank rates posted a better export performance in sectors intensive in tangible assets (Column 7). Moreover, this comparative advantage was markedly stronger during the financial crisis (Column $8, \beta_{2}>0$, significant at the $1 \%$ level).

Note that our results are consistent with Levchenko et al. (2010), who find weaker evidence for the role of trade credit in explaining sector-level trade flows during the crisis. Their analysis focuses on the cross-industry variation in access to trade credit. By contrast, we exploit both this cross-industry variation, as well as the cross-country variation in the cost of formal bank financing to uncover the role of TCRED. In addition, while they examine the annual change in trade between the second quarter of 2008 and the second quarter of 2009, we analyze the substantial movements in export patterns and credit conditions at the monthly frequency. Our findings thus suggest that the differential response of trade flows across countries and sectors, as well as the rapid unfolding of the crisis, are important factors for identifying the effects of credit conditions on cross-border activity.

\subsection{Sensitivity analysis}

While the extensive set of fixed effects in equation (1) go a long way towards mitigating concerns about omitted variables, we nevertheless perform a series of robustness tests.

We first confirm that our results are not driven by cross-country differences in factor endowments which may affect the pattern of export specialization. Specifically, we interact countries' initial physical and human capital per worker $\left(\log (K / L)_{i}\right.$ and $\left.\log (H / L)_{i}\right)$ respectively with measures of industry factor intensities $\left(\log (k / l)_{k}\right.$ and $\left.\log (h / l)_{k}\right)$, as well as with the crisis dummy. This is in the spirit of Romalis (2004), who finds that skill-abundant countries tend to export more in skill-intensive industries (likewise with physical capital). The only difference here is that we allow the strength of such factor-endowment motives for trade to change during the crisis. Since the double interaction terms between country endowments and industry factor intensities are subsumed by the country-industry fixed effects, we control only for the triple interaction terms, $D_{\text {crisis }} \times \log (K / L)_{i} \times \log (k / l)_{k}$ and $D_{\text {crisis }} \times \log (H / L)_{i} \times \log (h / l)_{k}$.

We also allow for the possibility that our measure of the cost of capital, IBrate, may be correlated with and thus picking up the effect of country size or overall level of development. To do so, we include the triple interactions of an initial measure of country GDP with $D_{\text {crisis }}$ and a full set of industry fixed 
effects. We also condition on a similar set of triple interactions based on initial country GDP per capita. (Once again, the double interactions of initial GDP and GDP per capita with industry fixed effects are subsumed by the $D_{i k}$ 's.)

Even with these controls for the role of country endowments, size and income, our main findings on the importance of credit conditions continue to hold. The triple interaction coefficients for EXTFIN and TCRED remain highly significant in Columns 3 and 6 (Table 2). While that for TANG is no longer statistically significant in Column 9, its point estimate retains the same sign and magnitude. In the tables that follow, we will report specifications that include this extended set of factor endowment, country size and income controls; the results are similar if these auxiliary controls are taken out.

Our findings are also robust to accounting for a number of particularities of our country sample, as shown in Table 3. Columns 1,4 and 7 report results treating the Euro-zone member countries as one cluster when computing the robust standard errors, for each of the three sector measures of financial vulnerability respectively. This helps to address the concern that interbank rates in the Euro zone track each other very closely because of the common monetary policy regime, so that the interbank rate observations from individual Euro-zone countries cannot be regarded as strictly independent. Reassuringly, our findings are unaffected by this correction. Columns 2, 5 and 8 confirm the stability of our results to removing the country with the highest interbank rates in the sample (Turkey). Columns 3, 6 and 9 likewise show that there is no substantial change when we exclude the economy with the lowest interbank rates (Japan), which also exhibits the smallest movements in IBrate over the sample period. In unreported regressions, we have further found that our conclusions hold when we drop the petroleum and coal products industry, this being the key sector for which price changes contributed more to the decline in US imports than quantity adjustments.

\section{[Table 3 about here.]}

Our results also obtain under different assumptions about the timing of the crisis period and with alternative interbank rate measures (Table 4). Under each financial vulnerability measure, the first column dates the start of the crisis to March 2008, the month of the Bear Stearns collapse, instead of September 2008. The second column lags the interbank rate by one month to account for the possibility that firms need to borrow in advance of the export delivery date. Finally, the third column uses the three-month instead of the one-month interbank rate. Our findings hold in all of these specifications with estimates of comparable magnitudes and levels of statistical significance, with the exception of the coefficients for $T A N G$ which are less precisely estimated.

\section{[Table 4 about here.]}

To summarize, countries with higher interbank rates and hence worse credit conditions recorded lower 
exports in financially vulnerable sectors, and this effect was more pronounced at the height of the crisis. Recall that over the course of the crisis period, interbank rates were generally decreasing as policies to ease the credit crunch took effect. Our findings thus highlight the contrast in cross-sector export performance that arose from the variation in the extent to which policies succeeded in lowering interbank rates in different countries. Note also that our results are particularly strong for TCRED in both quantitative and qualitative terms. This suggests that at the short-run monthly frequency, firms' access to trade credit matters more for the sensitivity of their exports to credit conditions relative to firms' long-term external capital requirements and their availability of collateral. This is corroborated by Appendix Table 3 , which reports joint tests including interactions with all three sector measures of financial vulnerability in the same regression. The signs and magnitudes of the point estimates obtained are similar to those in Table 2. However, while the coefficients for TCRED remain statistically significant, those for EXTFIN and $T A N G$ report larger standard errors. This likely reflects the fact that the coefficients are identified from the variation in three sector characteristics across a relatively small number of 21 industries.

In results available in a previous working paper version, we have also found that higher pre-crisis levels of financial development mitigated the adverse effects of the crisis. In particular, the exports of countries with stronger initial financial institutions (as measured by private credit as a share of GDP) were more resilient to the crisis in financially vulnerable sectors. It thus appears that both long-term institutional features of the financial system, as well as short-term fluctuations in the cost of capital, did influence the trade impact of the financial crisis.

\subsection{An illustration of the short-run effects of credit conditions}

Our main estimating equation (1) assumes that the crisis resulted in a one-time stepwise change in trade patterns. To illustrate how the effect of credit conditions on trade flows evolved as the financial crisis unfolded, we next relax this assumption and employ a more flexible regression specification:

$$
\ln Y_{i k t}=\sum_{m=1}^{M} \beta_{m} D_{m} \times \text { IBrate }_{i t} \times \operatorname{EXTFIN}_{k}+D_{i t}+D_{k t}+D_{i k}+\epsilon_{i k t}
$$

This allows the effect of credit conditions on the composition of exports to vary non-linearly over time, by using a full set of month dummies, $D_{m}$ (equal to 1 in month $m$ ) instead of the crisis indicator, and interacting each $D_{m}$ with the product of the interbank rate in country $i$ in month $t$ and the external finance dependence of industry $k$. The $D_{i t}, D_{k t}$ and $D_{i k}$ are country-month, industry-month, and countryindustry fixed effects as before.

We plot the $\beta_{m}$ coefficients estimated from (2) against time in Figure 3A. Figures 3B and 3C present similar graphs from using TCRED and TANG respectively. In each figure, the dotted lines indicate the $90 \%$ confidence intervals of each $\beta_{m}$ coefficient. Two linear regression trend lines for the $\beta_{m}$ 's are also 
shown, for the pre- and post-September 2008 periods.

\section{[Figure 3 about here.]}

Two patterns stand out. First, despite some month-to-month volatility, the coefficients on the interactions with EXTFIN are almost always negative, while those with TCRED and TANG are almost always positive. This reinforces our earlier conclusion that countries with higher interbank rates export systematically less in financially vulnerable sectors that require more external finance, enjoy less access to trade credit, or have few collateralizable assets.

Second, all three figures clearly indicate that the importance of credit conditions for the composition of exports increased dramatically as the crisis deepened. There is a pronounced break right around September 2008, the month we use as the start date for $D_{\text {crisis }}$ in our earlier analysis. This is consistent with the core results from the more parsimonious specification in (1).

Figure 3 naturally raises the question whether the severe and rapid crisis of 2008-2009 will have longlasting consequences for trade patterns. Put simply, will the global economy transition to a new steady state in which trade finance becomes a more important determinant of export patterns? Or will the relevance of credit conditions for trade ease off once this crisis is decisively behind us? Figure 3 suggests that EXTFIN became progressively more important for the sectoral composition of trade as the crisis unfolded, but also that TCRED and TANG became less salient over time. Based on this, we cannot conclusively determine whether the crisis has permanently raised the importance of credit channels of comparative advantage, and a complete verdict will have to await the availability of more data.

\subsection{Decomposing the interbank rate}

While we have so far been using the interbank rate as a proxy for the cost of capital, this can in turn be written as the sum of two components: (i) a baseline short-term lending rate, such as the rate on threemonth treasury bills; and (ii) the spread between the interbank rate and this baseline rate. Conceptually, the former reflects the baseline risk of systemic default in the financial system. On the other hand, the spread captures the premium required to additionally compensate lenders for the risk of default that is specific to interbank loans, and by extension to the commercial banking system. The finance literature has often measured credit conditions with this interbank spread, as it has historically widened when the perceived risk of bank default increased during periods of adverse credit or banking conditions.

In our benchmark analysis, we have used the interbank rate rather than the spread as the former in principle captures the total cost of capital that exporting firms have to incur. Moreover, to the extent that the countries in our sample are well-integrated financially, creditors around the world would presumably have access to the same baseline sovereign debt instrument, namely US treasuries. The spread would then be equal to the local interbank rate less that paid on three-month US treasury bills, otherwise known 
as the TED spread. ${ }^{17}$ But since the US treasury bill rate does not differ across exporting countries, its effect would already be fully absorbed in the estimation of (1) by the industry-month dummies. Given these fixed effects, we would in fact not be able to empirically disentangle the role of the interbank rate from that of the spread.

Notwithstanding these considerations, if borrowers in some countries lack ready access to US sovereign debt instruments, then the relevant spread measure should arguably be calculated using a local treasury bill rate. In this case, we can check which component of the overall cost of capital, namely the baseline treasury rate or the interbank spread, drives our baseline results. To this end, we use data on local three-month treasury bill rates from the IMF's International Financial Statistics, supplemented with information for missing countries from Global Financial Data. ${ }^{18}$ In all, data on local treasury rates are available for 21 out of the 31 countries in our sample. This incomplete country coverage is an important caveat to consider when interpreting our results here, as it may reduce the precision of our estimates.

Table 5 presents the results from re-estimating (1) using either local treasury bill rates or the spread between countries' interbank and treasury bill rates in place of our key IBrate explanatory variable. For each sector measure of financial vulnerability, we consistently find statistically significant effects that enter with the right predicted sign when using the baseline treasury bill rate (Columns 1, 3, 5). By contrast, the coefficients for the interbank spread are always imprecisely estimated (Columns 2, 4, 6). Together, these results indicate that changes in the baseline risk of systemic default were more important for the decline in trade flows than risks captured specifically by the interbank spread.

\section{[Table 5 about here.]}

These findings are not surprising upon closer inspection of the time series correlation between the interbank rate, the local three-month treasury rate and the interbank spread. The raw correlation between the interbank rate and the local treasury bill rate in the panel is 0.98 , while that between IBrate and the spread is a much smaller 0.18. For the mean country in our sample, the former correlation is 0.93 in the time series, with a tight standard deviation of 0.07 across countries. By contrast, the time-series correlation between the interbank rate and the spread is 0.24 for the average economy, and varies from -0.26 to $0.62 .^{19}$ The much tighter correlation between IBrate and the treasury rate indicates that the overall cost of capital was driven more by the baseline risk of default during this recent crisis. Our analysis would have missed out an important component of the cost of credit had we focused instead on the spread as a proxy for credit conditions.

\footnotetext{
${ }^{17}$ A commonly quoted TED spread is the London interbank offer rate (LIBOR) less the rate on three-month US treasuries.

${ }^{18}$ We took care to exclude countries in the IMF International Financial Statistics for which the reported treasury rates were not explicitly for a three-month maturity. For the Global Financial Data, we took the average of daily closing rates to calculate a monthly measure.

${ }^{19}$ The correlation between the three-month treasury rate and the interbank spread was even lower, varying from -0.78 to 0.26 and averaging -0.05 across the countries.
} 


\subsection{Effects on trade vs. production}

Our primary interest has been in the effect of the financial crisis on trade flows via the credit channel. It is nevertheless useful to ask whether this effect holds over and above that on domestic output. To the extent that both domestic producers and exporters incur the same costs in developing and manufacturing a product, they may be equally hurt by credit conditions. But exporters may be affected more because of the additional costs they bear that are specific to production for and shipping to foreign markets.

To explore this issue, we would ideally like to control on the right-hand side of (1) for each exporting country's sector-level industrial production at the monthly frequency. Such data are unfortunately not available for a large number of economies. Instead, we control for the monthly log industrial production index (IPI) in each sending country interacted with a full set of industry fixed effects. We also include the corresponding triple interactions with the crisis dummy. In this way we account as best we can for the overall effect of aggregate production on trade flows, while allowing the strength of this effect to vary freely across sectors, as well as during the crisis period. There are however two limitations to this approach: First, output fluctuations across different industries need not be proportional to those in aggregate production. Second, the IPI is not available for all the countries in our sample, so we face the potential problem of a loss of precision once again.

Bearing in mind these caveats, Table 6 does suggest that credit conditions had more severe repercussions for international trade than for domestic output. While the point estimates for EXTFIN and $T A N G$ remain largely unchanged, they are now less precisely estimated. The findings for TCRED, on the other hand, remain statistically and economically significant. This suggests that rising costs of capital had a larger effect on the pattern of trade than on the pattern of production, a conclusion which dovetails with the larger decline in trade flows relative to GDP reported in Freund (2009) and Levchenko et al. (2010). It is also consistent with the firm-level evidence in Amiti and Weinstein (2009) and Bricongne et al. (2010) that financial crises distort cross-border activity more than domestic transactions. In the same spirit but using country-level data for economies in steady state, Manova (2008b) finds that financial development allows countries to export relatively more in financially dependent sectors even controlling for domestic output by sector.

\section{[Table 6 about here.]}

\subsection{Teasing out the mechanisms}

What might explain the intensification of credit channels of comparative advantage during the crisis period? Recall from Figure 2 that the time path of interbank rates exhibits a fair amount of variation across countries, so that IBrate is not collinear with the crisis dummy, $D_{\text {crisis }}$. Our results therefore cannot be attributed simply to a non-linear effect of the cost of capital on export performance. We consider instead 
two potential explanations why countries with higher interbank rates may have experienced larger falls in their exports during the crisis, especially in financially vulnerable sectors.

First, the crisis period was marked by a sharp decline in the demand for imported final goods as households took a hit in their real estate and financial asset values. The prospect of job insecurity also dampened consumer sentiment. Producers in turn scaled down their output plans, prompting a reduction in the demand for imported intermediate inputs. While non-durable goods and services may have been more resilient, demand for imported manufactures as a whole collapsed. The anticipated decline in US market sales would have made it more difficult for foreign firms to raise trade financing to cover their fixed upfront costs, given that these firms would require sufficiently large export revenues to guarantee lenders a high enough expected return. Faced with tighter credit conditions, both the number of firms exporting from each country to the US, as well as the value of each firm's exports would contract in response to a sharp decline in US demand. This contraction would be amplified in countries with high interbank rates, and felt most acutely in financially vulnerable sectors. ${ }^{20}$

An alternative explanation recognizes that exporting firms may access trade financing not only in their home country, but also in their destination market. Exporters may directly obtain bank loans in the destination country, or receive trade credit that its import partner firm raises in its local market. It is thus possible that US imports fell because exporters found it more difficult to secure financing in the US during the crisis period. If exporters indeed depend on US credit markets, then adverse credit conditions in the US would be particularly burdensome on firms based in countries where external credit is limited, especially those firms engaged in financially vulnerable sectors. This interpretation raises the possibility that financial turmoil in one country can amplify the effect of credit tightening in its trade partners. $^{21}$

To explore these two explanations, we re-estimate equation (1) using proxies for US final goods demand and US credit supply conditions in place of the crisis dummy, $D_{\text {crisis. }}$. We use monthly data on log retail sales in the US from the US Census Bureau to measure movements in final goods demand. As an indicator of the availability of external finance in the US, we take the log value of US business and commercial loans extended by financial institutions in each month, from Federal Reserve releases. Since we expect higher demand or credit supply levels in the US to mitigate the effects of adverse credit conditions in exporting countries, we anticipate the triple interactions with these variables to both enter with the opposite sign to those with $D_{\text {crisis }}$. Finding significant coefficients for the interactions with retail sales or business loans would then provide support for one or both of the above explanations. However, to the extent that these variables are imperfect measures, we may not be able to entirely reject

\footnotetext{
${ }^{20}$ This logic can be formalized using a model with credit constraints and firm heterogeneity, as in Manova (2008a).

${ }^{21}$ This is consistent with the theory and evidence in Manova (2008a), Antràs et al. (2009) and Manova et al. (2009) that foreign portfolio flows and foreign direct investment can compensate for underdeveloped domestic financial markets.
} 
a mechanism based on insignificant coefficients.

The evidence in Table 7 suggests that the sharp drop in US demand was more decisive than tighter US loan supply in explaining why exports to the US became particularly sensitive to credit conditions at the height of the crisis. While countries with higher interbank rates on average exported less in sectors more reliant on external finance, this distortion was alleviated during months of stronger demand in the US (Column 1). On the other hand, reductions in US loan supply did not seem to intensify the impact of credit conditions in the sending country (Column 2). These conclusions are further confirmed by the horse-race in Column 3: When we include interactions with both US demand and US credit supply in the same regression, the former continues to play a statistically significant role, while the latter no longer does. Qualitatively similar patterns obtain when we instead consider the variation across sectors with different access to trade credit, although the results are weaker with our final financial vulnerability variable, $T A N G .^{22}$

\section{[Table 7 about here.]}

In our working paper version, we also pursued an alternative approach to evaluate the role of credit availability in the destination country. Instead of examining US imports, we considered US exports by destination country and sector as the outcome variable. We regressed it on the interactions of the interbank rate in the importing market with sectors' financial dependence and the crisis dummy. The largely insignificant effects we found offer further suggestive evidence that the cost of capital at the export dock is substantially more important for trade activity than that in the importing country.

\section{Level effects of credit conditions on trade flows}

The econometric approach in Section 5 exploits the variation in financial vulnerability across sectors, and permits the inclusion of a demanding set of fixed effects. This alleviates concerns regarding omitted variables, and allows us to isolate a plausibly causal effect of credit conditions on trade flows during the financial crisis. However, it precludes an evaluation of the level effect of credit conditions. We now examine this level effect, so that we can later quantify the impact of credit conditions during the crisis on overall trade volumes.

\footnotetext{
${ }^{22}$ We have also run specifications in which the triple interaction with the US final demand and/or credit supply proxies enter together with the triple interaction using the crisis dummy (available on request). The crisis dummy term generally tends to be more robustly significant than the US retail sales and/or business loans interactions, with the latter two often losing statistical significance. In particular, this means either that our US final demand proxies are relatively noisy variables or that the US final demand story does not fully explain the intensification during the crisis period.
} 


\subsection{Cross-country estimation}

We first study the impact of the crisis on trade flows across exporting countries with varying levels of the cost of capital. In particular, we estimate the following:

$$
\ln Y_{i k t}=\gamma_{1} \text { IBrate }_{i t}+\gamma_{2} D_{\text {crisis }} \times \text { IBrate }_{i t}+D_{k t}+\epsilon_{i k t}
$$

As before, $Y_{i k t}$ and IBrate $_{i t}$ are respectively the value of US imports from country $i$ in industry $k$ and the interbank rate in that country during month $t . D_{\text {crisis }}$ is again a binary variable equal to 1 between September 2008 and August 2009. We include industry-month fixed effects which subsume the average effect of the crisis on US sectoral imports. These also control for fluctuations in sector-specific US import demand, as well as for monthly seasonality in the data. We further condition on the log monthly-averaged nominal bilateral exchange rate with the US dollar $\left(\log E X C H_{i t}\right)$ and its interaction with the crisis dummy $\left(D_{\text {crisis }} \times \log E X C H_{i t}\right)$, to account for any effects that exchange rate movements may have had on trade flows. These can now be identified because we do not include country-month fixed effects in the regression. ${ }^{23}$ We report standard errors clustered by country, but the results are similar when clustering by country-industry.

The coefficients of interest, $\gamma_{1}$ and $\gamma_{2}$, are now identified from the variation in the cost of capital across exporting countries in a given month and sector. The main effect of IBrate $i t$ thus establishes the extent to which countries with cheaper credit are able to export more to the US. The interaction term in turn identifies the impact of credit tightness on trade flows at the height of the crisis.

As Table 8 documents, countries with lower interbank rates systematically exported more to the US (Column 1). This effect is statistically significant at the $10 \%$ level, with the point estimate implying that a one percentage point rise in the cost of bank financing would be associated with approximately a $16 \%$ drop in that country's exports to the US market. This result is consistent with the broader body of evidence in the prior literature demonstrating that financial frictions constrain firms' export levels, or even prevent firms from exporting altogether.

\section{[Table 8 about here.]}

We also find that tight credit conditions became particularly damaging to a country's exports during the crisis. While the point estimate of $\gamma_{2}$ is negative but not significant in Column 2, this finding strengthens considerably when we further control for cross-country differences in per worker factor endowments, GDP and GDP per capita, along with their respective interactions with the crisis dummy (Columns 3 and $4 ; \gamma_{2}$ now significant at the $5 \%$ level). Column 5 explores the extent to which credit conditions during the crisis were disproportionately damaging for trade flows relative to overall production.

\footnotetext{
${ }^{23}$ Our results are not particularly sensitive to this control as exchange rates moved relatively little during this period compared to the interbank rate and trade volumes. The effect of $\log E X C H_{i t}$ itself shows up as expected, with a stronger exporter exchange rate associated with lower exports to the US (results available on request).
} 
We control here for countries' log industrial production index, as well as its interaction with the crisis dummy. In contrast to our earlier findings in Section 5.4, we now find weaker evidence that financial frictions restricted the overall volume of cross-border activity over and above total output.

\subsection{Within-country estimation}

To what extent were these level effects of the interbank rate also manifest in the within-country experience? To this end, we consider a more stringent specification that includes country-industry fixed effects $\left(D_{i k}\right)$. We estimate the following fully saturated model:

$$
\ln Y_{i k t}=\gamma_{1} \text { IBrate }_{i t}+D_{k t}+D_{i k}+\epsilon_{i k t}
$$

The $D_{i k}$ 's now control for time-invariant determinants of comparative advantage that affect the average pattern of country exports across sectors, including the average effect that high interbank rates might have on financially vulnerable sectors. These also control for all other country characteristics that are relatively stable over time. The coefficient of interest, $\gamma_{1}$, is thus identified purely from the variation in the cost of capital within countries over time, and abstracts from the variation in the (average) interbank rate in the cross-section of countries. In practice, we estimate (4) for different subperiods in our sample, to explore whether the level effect of the interbank rate varied over time. This is similar in spirit to (3), but slightly more flexible in that it does not impose a stepwise change during the crisis period.

We report results for the full sample period in the top panel of Table 9. In contrast to our findings in Table 8 which were based on the cross-country variation in IBrate, we now document a positive but smaller within-country association between exporting countries' interbank rates and sales to the US (Column 1, significant at the $5 \%$ level). This result is not driven by movements in the bilateral exchange rates against the US dollar (Column 2). However, it is not robust to controlling for exporters' industrial production index (Column 3). It also does not survive a number of other sensitivity checks, including treating Europe as a cluster, dropping the petroleum and coal products industry, or lagging the interbank rate (available on request). ${ }^{24}$

\section{[Table 9 about here.]}

We next break the sample into three subperiods that correspond to the months before the crisis unfolded in earnest (November 2006 to August 2008), the most acute stage of the crisis (September 2008 to December 2008), and the remainder of the sample period (January 2009 to October 2009). As the rest of Table 9 shows, this breakdown allows us to uncover a strong and very robust negative relationship between a country's interbank rate and export performance at the very peak of the financial crisis. On

\footnotetext{
${ }^{24}$ When we include $D_{\text {crisis }} \times$ IBrate ${ }_{i t}$ in this regression for the full sample period, the results are similar to the top panel in Table 9. $D_{\text {crisis }} \times I$ Brate $i t$ typically yields a positive though frequently insignificant coefficient (available on request).
} 
the other hand, no systematic pattern emerges for the periods before or after this peak. (We have experimented with extending the most acute phase of the crisis, either with an earlier start or a later end month. The correlation between IBrate and log exports tends to become successively less negative as we expand this period, before eventually turning positive and insignificant.)

How should we interpret these results? The prevailing cost of credit in an economy reflects the equilibrium between the demand for external capital and the supply of such financing. During normal economic times, interbank rates tend to be higher during business cycle peaks, reflecting firms' increased demand for bank financing in order to service attractive investment and export opportunities. By contrast, during a period of unusual financial turmoil as was the case during the recent crisis, higher interbank rates likely capture instead the limited availability of capital. Our results suggest that the latter effect dominated during the height of the crisis. Since the September through December 2008 months were generally marked by falling interbank rates as monetary policies were eased, our results imply that countries where the cost of capital did not fall as much had a worse overall trade performance than countries where interbank rates fell more substantially.

It is important to emphasize that these findings do not contradict our earlier results in Table 8 . In particular, the sector-month fixed effects in (3) control for changes in US import demand that affect all exporting countries equally. The effects of the interbank rate are thus identified primarily from crosscountry differences on the supply side, namely credit availability, and it may indeed be the case that credit availability was generally higher and export performance stronger in countries with lower average interbank rates. On the other hand, the additional country-industry fixed effects in (4) ensure that the effect of the interbank rate in Table 9 is identified from time-series fluctuations in both supply and demand within each exporting country. Our results in Tables 8 and 9 are also consistent with our findings on the differential effect of the crisis across sectors in Section 5. Regardless of whether a high interbank rate is due to strong demand for capital or a shortage of credit supply, firms in financially vulnerable sectors would be constrained in their ability to expand due to their higher sensitivity to the cost of credit.

\section{Interpreting the magnitudes}

Sections 5 and 6 provide strong evidence that credit conditions were an important determinant of aggregate trade flows and their sectoral composition during the height of the global financial crisis. These results reflect the importance of the cost of securing short-term financing, as proxied by the interbank rate, for exporting activity. In this section, we perform some exercises to gauge the contribution of changing credit conditions to the overall trade collapse witnessed during the crisis.

To do so, we use our regression estimates to infer how US imports would have evolved under two 
alternative scenarios. First, we evaluate the hypothetical impact on trade had interbank rates remained at their peak levels of September 2008 throughout the crisis period. We then consider the opposite extreme, assuming that interbank rates had dropped immediately after September 2008 to their low levels of August 2009. These two calculations provide rough upper and lower bounds respectively for the damage that the crisis could have inflicted on trade flows specifically through the credit channel.

It is tempting to interpret the first scenario as one in which the policy response by monetary authorities to ease credit conditions was not effective, resulting in persistently high interbank rates. Conversely, the latter scenario might be viewed as one of exceptionally aggressive policy interventions to lower interbank rates. We would however caution that our analysis is not a precise policy evaluation. Given the reducedform nature of our empirical approach, our point estimates are not strictly adequate for projecting the general equilibrium effects of policies. We instead view this exercise as providing a ballpark estimate to make sense of how much credit conditions affected international trade flows.

\subsection{Case 1: persistently high cost of credit}

We first examine the scenario where the interbank rate in each country remains fixed at its peak September 2008 level through August 2009. To proceed, we use our regression point estimates and the actual interbank rates to obtain the predicted US imports from each country and sector. We then compare these against the predicted trade flows under the counterfactual path of interest rates.

To infer the additional decline in overall trade volumes that would have resulted, we first consider the estimates from equation (3). Recall that in this specification, the level effect of credit conditions is estimated primarily from the cross-country variation in the cost of capital. Based on Column 2 of Table 8, we find that the US would have imported $35.2 \%$ less from the average country and sector between September 2008 and August 2009, had interbank rates remained at their elevated September 2008 levels.

These figures of course rely on a less-restrictive specification. A more conservative estimate of the trade impact of the crisis can be obtained using equation (4), which was estimated purely from the within-country movements in the cost of capital over time. Based on Column 2 of the "Sep 08 to Dec 08" panel in Table 9, we find that the crisis would have lowered US imports by an additional $2.5 \%$ over this period had interest rates remained at their peak levels. While this impact is considerably less severe, it is nevertheless quite sizable when considered against the overall $12 \%$ drop in world trade flows for the whole of 2009. This magnitude is also in line with recent estimates on the firm-level impact of the crisis: Using French micro data, Bricongne et al. (2010) find that firms which had defaulted on a payment in the preceding 12 months, and hence presumably had limited access to finance during the crisis, subsequently saw a $2 \%$ worse export performance relative to firms that did not experience such a payments incident.

Our results naturally point to a more severe impact on trade flows in financially vulnerable sectors. To 
quantify the size of these cross-sector effects, we use the estimates from the triple interaction regression in (1), specifically the estimates from Columns 2, 5 and 8 in Table 2. If all countries' interbank rates had stayed at their September 2008 levels until the end of August 2009, US imports would have been $13.4 \%$ lower in the most external finance-dependent sector (chemical manufacturing) relative to the least dependent sector (leather and allied products). Similarly, countries would have exported $16.9 \%$ less on average in the sector with the least availability of trade credit (textiles) relative to the sector with the greatest access (petroleum and coal products). Finally, trade would have been $17 \%$ weaker in the industry with the lowest share of tangible assets (leather and allied manufacturing) relative to the industry with the hardest assets (petroleum and coal products).

\subsection{Case 2: instantaneous drop in the cost of credit}

We next consider the converse scenario, under which the interbank rate in each country drops to its low August 2009 level immediately after September 2008. To gauge how much higher trade flows would have been, we once again use our point estimates from the respective regressions described in the previous subsection. This time, we compare the predicted trade flows under the actual interbank rates to those under the assumption of permanently low rates after September 2008.

We conservatively conclude that the 2008-2009 crisis would have hurt overall US imports by $5.5 \%$ less under this scenario (based on the Table 9 specification). Our estimates from the less restrictive specification that uses the full cross-country variation in credit conditions indicate that this magnitude may be as high as a $30.5 \%$ improvement (based on the Table 8 specification). Once again, trade flows in financially vulnerable sectors would have benefited disproportionately more from the increased availability of cheaper external credit. The difference in export performance between the most and least external capital-dependent industries would have been $8.2 \%$. The corresponding difference when con-

sidering industries' access to trade credit or endowment of tangible assets would have been a $9.7 \%$ gap (coincidentally equal for both sector measures).

These hypothetical scenarios provide a sense of the large impact of financial market disturbances on the real economy. They also indirectly suggest that policy interventions that lowered the cost of capital were quite important in averting a substantially more severe collapse in trade flows. At the same time, the effect of the crisis would have been significantly milder had credit conditions improved faster.

\section{Conclusion}

This paper is one of the first to establish and quantify the effect that credit conditions had on international trade during the 2008-2009 global financial crisis. Using monthly data on US imports, we find that countries with higher interbank rates and thus tighter credit conditions exported less to the US during 
the crisis period. These effects were especially pronounced in sectors that require extensive external financing, have limited access to buyer-supplier trade credit, or have few collateralizable assets. In other words, exports of financially vulnerable industries were more sensitive to the cost of external capital than exports of less vulnerable industries, and this sensitivity rose during the financial crisis. This impact of credit conditions on trade flows holds even after controlling as best we can for domestic production, so that the financial market disruptions mattered for international trade over and above their effect on output per se.

Our findings imply that adverse credit conditions played an important role in the transmission of the effects of the crisis to international trade flows. They also suggest that policy interventions that contributed towards relaxing the high cost of capital substantially dampened the detrimental impact on cross-border trade. For example, our most conservative estimates indicate that US imports would have fallen by about $2.5 \%$ more had interest rates persisted at their peak September 2008 levels.

In sum, our paper provides further evidence of the effect of credit conditions on trade, particularly during a severe shock to the banking and financial sector. It highlights the potential gains from interventions targeting access to external finance, and sheds light on the role of such policies in mitigating the uneven impact of the crisis on trade flows across countries and sectors.

\section{$9 \quad$ References}

Alessandria, G., Kaboski, J.P., Midrigan, V., 2010. The great trade collapse of 2008-09: an inventory adjustment? IMF Economic Review 58, 254-294.

Amiti, M., Weinstein, D., 2009. Exports and financial shocks. NBER Working Paper 15556.

Antràs, P., Desai, M., Foley, C.F., 2009. Multinational firms, FDI flows and imperfect capital markets. Quarterly Journal of Economics 124, 1171-1219.

Auboin, M., 2009. Boosting the availability of trade finance in the current crisis: background analysis for a substantial G20 package. Centre for Economic Policy Research Policy Research No. 35.

Bartelsman, E.J., Becker, R.A., Gray, W.B., 2000. NBER-CES Manufacturing Industry Database.

Beck, T., 2002. Financial development and international trade: is there a link? Journal of International Economics 57, 107-131.

Beck, T., 2003. Financial dependence and international trade. Review of International Economics 11, 296-316.

Beck, T., Demirgüc-Kunt, A., Levine, R., 2009. A new database on financial development and structure. World Bank mimeo.

Becker, B., Greenberg, D., 2007. Financial development, fixed costs and international trade. Harvard Business School mimeo.

Behrens, K., Corcos, G., Mion, G., 2010. Trade crisis? What trade crisis? CEPR Discussion Paper 7956.

Bems, R., Johnson, R.C., Yi, K.M., 2010. The role of vertical linkages in the propagation of the global downturn of 2008. Federal Reserve Bank of Philadelphia mimeo. 
Berman, N., Martin, P., 2010. The vulnerability of sub-saharan Africa to the financial crisis: the case of trade. CEPR Discussion Paper 7765.

Borchert, I., Mattoo, A., 2009. The crisis-resilience of services trade. World Bank Policy Research Working Paper 4917.

Braun, M., 2003. Financial contractibility and asset hardness. University of California-Los Angeles mimeo.

Braun, M., Larrain, B., 2005. Finance and the business cycle: international, inter-industry evidence. Journal of Finance 40, 1097-1128.

Bricongne, J.C., Fontagné, L., Gaulier, G., Taglioni, D., Vicard, V., 2010. Firms and the global crisis: French exports in the turmoil. Bank of France mimeo.

Brunnermeier, M.K., 2009. Deciphering the liquidity and credit crunch 2007-08. Journal of Economic Perspectives 23(1), 77-100.

Campello, M., Graham, J., Harvey, C., 2010. The real effects of financial constraints: evidence from a financial crisis. Journal of Financial Economics 97, 470-487.

Caselli, F., 2005. Accounting for cross-country income differences. In: Aghion, P., Durlauf, S. (Eds.), Handbook of Economic Growth. North-Holland, Amsterdam.

Chaney, T., 2005. Liquidity constrained exporters. University of Chicago mimeo.

Chauffour, J.P., Farole, T., 2009. Trade finance in crisis: market adjustment or market failure? World Bank Policy Research Working Paper 5003.

Claessens, S., Laeven, L., 2003. Financial development, property rights, and growth. Journal of Finance 58, 2401-2436.

Dell'Ariccia, G., Detragiache, E., Rajan, R., 2008. The real effect of banking crises. Journal of Financial Intermediation 17, 89-112.

Djankov, S., Freund, C., Pham, C.S., 2010. Trading on time. Review of Economics and Statistics 92, 166-173.

Do, Q.T., Levchenko, A.A., 2007. Comparative advantage, demand for external finance, and financial development. Journal of Financial Economics 86, 796-834.

Eaton, J., Kortum, S., Neiman, B., Romalis, J., 2010. Trade and the global recession. University of Chicago mimeo.

Ellingsen, T., Vlachos, J., 2009. Trade finance in a liquidity crisis. World Bank Policy Research Working Paper 5136.

Evenett, S.J., 2009. What can be learnt from crisis-era protectionism? An initial assessment. The Berkeley Electronic Press Journals: Business and Politics 11, Article 4.

Feenstra, R.C., Romalis, J., Schott, P.K., 2002. US imports, exports and tariff data.

Fisman, R., Love, I., 2003. "Trade credit, financial intermediary development, and industry growth. Journal of Finance 58, 353-374.

Freilich, E., McGeever, J., 2009. Euro Libor dips, US commercial paper up. Reuters.com, October 1.

Freund, C., 2009. The trade response to global downturns. World Bank Policy Research Working Paper 5015.

Greenaway, D., Guariglia, A., Kneller, R., 2007. Financial factors and exporting decisions. Journal of International Economics 73, 377-395. 
Haddad, M., Harrison, A., Hausman, C., 2010. Decomposing the great trade collapse: products, prices, and quantities in the 2008-2009 crisis. NBER Working Paper 16253.

Hall, R., Jones, C., 1999. Why do some countries produce so much more output per worker than others? Quarterly Journal of Economics 114, 83-116.

Healy, J., 2009. 62,000 jobs are cut by U.S. and foreign companies. The New York Times, January 27.

Heston, A., Summers, R., Aten, B., 2006. Penn World Table Version 6.2. Center for International Comparisons of Production, Income and Prices at the University of Pennsylvania.

Hur, J., Raj, M., Riyanto, Y., 2006. The impact of financial development and asset tangibility on export. World Development 34, 1728-1741.

Iacovone, L., Zavacka, V., 2009. Banking crises and exports: lessons from the past. World Bank Policy Research Working Paper 5016.

IMF-BAFT, 2009. A survey among banks assessing the current trade finance environment.

Ju, J., Wei, S.J., 2008. When is quality of financial system a source of comparative advantage? NBER Working Paper 13984.

Kee, H.L., Neagu, C., Nicita, A., 2010. Is protectionism on the rise? Assessing national trade policies during the crisis of 2008. World Bank Policy Research Working Paper 5274.

Keogh, B., 2008. Libor rises, commercial paper slumps as credit freeze deepens. Bloomberg.com, October 2.

Kletzer, K., Bardhan, P., 1987. Credit markets and patterns of international trade. Journal of Development Economics 27, 57-70.

Kroszner, R.S., Laeven, L., Klingebiel, D., 2007. Banking crises, financial dependence, and growth. Journal of Financial Economics 84, 187-228.

Levchenko, A.A., Lewis, L., Tesar, L.L., 2010. The collapse of international trade during the 2008-2009 crisis: in search of the smoking gun. IMF Economic Review 58, 214-253.

Manova, K., 2008a. Credit constraints, equity market liberalizations and international trade. Journal of International Economics 76, 33-47.

Manova, K., 2008b. Credit constraints, heterogenous firms, and international trade. NBER Working Paper 14531.

Manova, K., Wei, S.J., Zhang, Z., 2009. Credit constraints and international trade: a firm-level analysis. Stanford University mimeo.

Malouche, M., 2009. Trade and trade finance developments in 14 developing countries post September 2008: a world bank survey. World Bank Policy Research Working Paper 5138.

Matsuyama, K., 2005. Credit market imperfections and patterns of international trade and capital flows. Journal of the European Economic Association 3, 714-723.

McKibbin, W.J., Stoeckel, A., 2009. The potential impact of the global financial crisis on world trade. World Bank Policy Research Working Paper 5134.

Minetti, R., Zhu, S.C., 2010. Credit constraints and firm export: microeconomic evidence from Italy. Forthcoming, Journal of International Economics.

Mora, J., Powers, W., 2009. Did trade credit problems deepen the great trade collapse? VoxEU.org, 27 November.

Muûls, M., 2008. Exporters and credit constraints. A firm level approach. London School of Economics mimeo. 
Raddatz, C., 2006. Liquidity needs and vulnerability to financial underdevelopment. Journal of Financial Economics 80, 677-722.

Rajan, R., Zingales, L., 1998. Financial dependence and growth. American Economic Review 88, 559586.

Rampell, C., 2009. Layoffs spread to more sectors of the economy. The New York Times, January 27.

Romalis, J., 2004. Factor proportions and the structure of commodity trade. American Economic Review 94, 67-97.

Schwartz, N., 2009a. Job losses pose a threat to stability worldwide. The New York Times, February 15.

Schwartz, N., 2009b. Rapid declines in manufacturing spread global anxiety. The New York Times, March 20.

Svaleryd, H., Vlachos, J., 2005. Financial markets, the pattern of industrial specialization and comparative advantage. European Economic Review 49, 113-144.

Yi, K.M., 2003. Can vertical specialization explain the growth of world trade? Journal of Political Economy 111, 52-102.

\section{Data Appendix}

\section{A. Trade flows}

US trade flows: From the US Census Bureau Foreign Trade Statistics. Monthly data at the 3-digit NAICS level is used.

\section{B. Industry characteristics}

External capital dependence (EXTFIN): Constructed following Rajan and Zingales (1998). See Section 3.

Trade credit (TCRED): Constructed following Fisman and Love (2003). See Section 3.

Asset tangibility ( $T A N G$ ): Constructed following Braun (2003). See Section 3.

Factor intensities $(\log (k / l), \log (h / l))$ : From the NBER-CES database. These are constructed first for SIC 4-digit industries: (i) Physical capital intensity as the log of the ratio of real capital stock to total employment; and (ii) Skill intensity as the log of the ratio of non-production workers to total employment. These are calculated using 1996 data, the most recent year available. We map SIC 4-digit to NAICS 3-digit industries using concordance weights between the two classification systems constructed from US import volumes from 1989-2006, obtained from the Feenstra et al. (2002) database. The factor intensity of each NAICS 3-digit industry is the concordance-weighted average of the factor intensities of its constituent SIC 4-digit industries.

\section{Country variables}

Interbank rates (IBrate): See Section 3.

Factor abundance $(\log (K / L), \log (H / L))$ : Based on Caselli (2005) and the Penn World Tables, Version 6.2 (Heston et al. 2006). Physical capital stock is calculated using the perpetual inventory method, namely: $K_{t}=I_{t}+\delta K_{t-1}$, where $I_{t}$ is investment and $\delta=0.06$ is the assumed depreciation rate. The investment flow and labor force data are from the latest version of the Penn World Tables. Human 
capital per worker is taken from Caselli (2005). Following Hall and Jones (1999), $H / L$ is calculated as a Mincerian return-weighted average years of schooling, namely $H / L=\exp (\phi(s))$, where $s$ is the average years of schooling in the population over 25 years of age, and $\phi(\cdot)$ is a piece-wise linear function with a slope of 0.13 for $s<4,0.10$ for $4<s<8$, and 0.07 for $s>8$. We use the average value of $K / L$ and $H / L$ over 1996-2005 as our measures of initial factor endowments.

Exchange rates: From Thomson Datastream, in units of foreign currency per US dollar. A monthly average of daily rates is used.

Treasury Bill rate: Three-month rate. From the IMF International Financial Statistics; countries for which the reported treasury bill rate was not explicitly documented to be for a three-month maturity were dropped. Supplemented for some additional countries by information from the Global Financial Data; a monthly average of daily closing rates was used.

Industrial Production Index: From the IMF International Financial Statistics.

GDP and GDP per capita: From the World Development Indicators (WDI), in PPP units. Averaged over 1996-2005.

US retail sales: Seasonally adjusted. From the US Census Bureau.

US business loans: Total commercial and industrial loans at all US commercial banks, seasonally adjusted. From the Board of Governors of the Federal Reserve System H.8 release. 
Table 1

The Month-on-Month Fall in US Manufacturing Imports (Oct-Nov 2008)

A: Industries (NAICS 3-digit) with sharpest declines in imports (top 5)

\begin{tabular}{lll}
\hline \hline 324: & Petroleum and Coal Products Manufacturing & $-54.0 \%$ \\
315: & Apparel Manufacturing & $-33.3 \%$ \\
331: & Primary Metal Manufacturing & $-23.7 \%$ \\
316: & Leather and Allied Product Manufacturing & $-22.6 \%$ \\
335: & Electrical Equipment, Appliance, and Component Manufacturing & $-22.3 \%$ \\
\hline \hline
\end{tabular}

B: Industries (NAICS 3-digit) with smallest declines in imports (bottom 5)

\begin{tabular}{lll}
\hline \hline 321: & Wood Product Manufacturing & $-12.3 \%$ \\
336: & Transportation Equipment Manufacturing & $-11.8 \%$ \\
326: & Plastics and Rubber Products Manufacturing & $-10.1 \%$ \\
311: & Food Manufacturing & $-7.3 \%$ \\
337: & Furniture and Related Product Manufacturing & $-5.5 \%$ \\
\hline \hline
\end{tabular}

Notes: Calculated from US Census Bureau Data on US imports from the rest of the world. 
Table 2

Effects of the Crisis on Trade across Countries and Sectors

\begin{tabular}{|c|c|c|c|c|c|c|c|c|c|}
\hline \multirow{3}{*}{$\begin{array}{l}\text { Crisis }=1: \text { Sep } 08 \text { to Aug } 09 \\
\text { Fin Vulnerability measure: }\end{array}$} & \multicolumn{9}{|c|}{ Dependent variable: Log (Industry exports to the US) } \\
\hline & \multicolumn{3}{|c|}{ EXTFIN } & \multicolumn{3}{|c|}{ TCRED } & \multicolumn{3}{|c|}{ TANG } \\
\hline & (1) & (2) & (3) & (4) & (5) & (6) & (7) & (8) & (9) \\
\hline IBrate X Fin Vuln & $\begin{array}{c}-0.006 \\
{[0.005]}\end{array}$ & $\begin{array}{c}-0.001 \\
{[0.003]}\end{array}$ & $\begin{array}{c}0.000 \\
{[0.003]}\end{array}$ & $\begin{array}{c}0.565^{\star} \\
{[0.293]}\end{array}$ & $\begin{array}{c}0.281 \\
{[0.275]}\end{array}$ & $\begin{array}{c}0.288 \\
{[0.311]}\end{array}$ & $\begin{array}{l}0.152^{\star} \\
{[0.081]}\end{array}$ & $\begin{array}{c}0.120 \\
{[0.092]}\end{array}$ & $\begin{array}{c}0.137 \\
{[0.109]}\end{array}$ \\
\hline Crisis $X$ IBrate $X$ Fin Vuln & & $\begin{array}{l}-0.007^{\star} \\
{[0.004]}\end{array}$ & $\begin{array}{l}-0.009 * * \\
{[0.004]}\end{array}$ & & $\begin{array}{l}0.495^{\star * *} \\
{[0.109]}\end{array}$ & $\begin{array}{l}0.587^{\star * \star} \\
{[0.174]}\end{array}$ & & $\begin{array}{l}0.057^{\star \star \star} \\
{[0.017]}\end{array}$ & $\begin{array}{l}0.057 \\
{[0.041]}\end{array}$ \\
\hline Factor endowments controls & No & No & Yes & No & No & Yes & No & No & Yes \\
\hline Initial size \& income controls & No & No & Yes & No & No & Yes & No & No & Yes \\
\hline Cty-Ind, Cty-Mth, Ind-Mth fixed effects & Yes & Yes & Yes & Yes & Yes & Yes & Yes & Yes & Yes \\
\hline Observations & 22,901 & 22,901 & 20,208 & 22,901 & 22,901 & 20,208 & 22,901 & 22,901 & 20,208 \\
\hline R-squared & 0.964 & 0.964 & 0.965 & 0.964 & 0.964 & 0.965 & 0.964 & 0.964 & 0.965 \\
\hline
\end{tabular}

Notes: Standard errors are clustered by country, with ***, **, and * denoting significance at the $1 \%, 5 \%$, and $10 \%$ levels respectively. The dependent variable is log monthly exports to the US in 3-digit NAICS manufacturing industries, covering Nov 06 to Oct 09. All specifications include country-industry, country-month, and industry-month fixed effects. The Crisis variable is an indicator equal to 1 from Sep 08 to Aug 09. The financial vulnerability measure in Columns (1)-(3) is EXTFIN, that in Columns (4)-(6) is TCRED, and that in Columns (7)-(9) is TANG. For each financial vulnerability measure, the first two columns are lean specifications containing no auxillary controls. The third column includes factor endowment controls $(C$ risis $X$ Log(K/L) $X$ Log(K/l) and Crisis $X \log (H / L) X \log (h / l))$, as well as country size and income controls (Crisis $X \log (G D P) X$ Industry fixed effects and Crisis X Log(GDPpc) X Industry fixed effects). 
Table 3

Robustness I: Country Sample

\begin{tabular}{|c|c|c|c|c|c|c|c|c|c|}
\hline \multirow{4}{*}{$\begin{array}{l}\text { Crisis = 1: Sep } 08 \text { to Aug } 09 \\
\text { Fin Vulnerability measure: }\end{array}$} & \multicolumn{9}{|c|}{ Dependent variable: Log (Industry exports to the US) } \\
\hline & \multicolumn{3}{|c|}{ EXTFIN } & \multicolumn{3}{|c|}{ TCRED } & \multicolumn{3}{|c|}{ TANG } \\
\hline & (1) & $(2)$ & (3) & (4) & $(5)$ & (6) & (7) & (8) & (9) \\
\hline & EU cluster & Less TUR & Less JPN & EU cluster & Less TUR & Less JPN & EU cluster & Less TUR & Less JPN \\
\hline \multirow[t]{2}{*}{ IBrate X Fin Vuln } & 0.000 & 0.004 & -0.000 & 0.288 & 0.300 & 0.472 & 0.137 & 0.048 & 0.142 \\
\hline & {$[0.003]$} & [0.003] & {$[0.003]$} & {$[0.314]$} & [0.527] & [0.339] & [0.109] & [0.148] & [0.118] \\
\hline Crisis $X$ IBrate $X$ Fin Vuln & $-0.009 * *$ & $-0.014^{*}$ & $-0.009 * *$ & $0.587^{\star \star \star}$ & $0.675^{\star \star}$ & $0.541^{* \star *}$ & 0.057 & $0.132^{* *}$ & 0.059 \\
\hline Factor endowments controls & Yes & Yes & Yes & Yes & Yes & Yes & Yes & Yes & Yes \\
\hline Initial size \& income controls & Yes & Yes & Yes & Yes & Yes & Yes & Yes & Yes & Yes \\
\hline Cty-Ind, Cty-Mth, Ind-Mth fixed effects & Yes & Yes & Yes & Yes & Yes & Yes & Yes & Yes & Yes \\
\hline Observations & 20,208 & 19,461 & 19,452 & 20,208 & 19,461 & 19,452 & 20,208 & 19,461 & 19,452 \\
\hline R-squared & 0.965 & 0.966 & 0.964 & 0.965 & 0.966 & 0.964 & 0.965 & 0.966 & 0.964 \\
\hline
\end{tabular}

Notes: See notes to Table 2. Standard errors are clustered by country, with ${ }^{* * *},{ }^{* *}$, and ${ }^{*}$ denoting significance at the $1 \%, 5 \%$, and $10 \%$ levels respectively. For each financial vulnerability measure, the first column treats the Euro zone countries as a group when clustering the standard errors, while the second and third columns drop Turkey and Japan respectively. All columns include the factor endowment controls, as well as the country size and income countrols.

Table 4

Robustness II: Crisis Date and Interbank Rate Measures

\begin{tabular}{|c|c|c|c|c|c|c|c|c|c|}
\hline \multirow{3}{*}{$\begin{array}{l}\text { Crisis }=1: \text { Sep } 08 \text { to Aug } 09 \\
\text { Fin Vulnerability measure: }\end{array}$} & \multicolumn{9}{|c|}{ Dependent variable: Log (Industry exports to the US) } \\
\hline & \multicolumn{3}{|c|}{ EXTFIN } & \multicolumn{3}{|c|}{ TCRED } & \multicolumn{3}{|c|}{ TANG } \\
\hline & $(1)$ & $(2)$ & (3) & $(4)$ & (5) & (6) & $(7)$ & (8) & (9) \\
\hline \multirow[t]{2}{*}{ IBrate $X$ Fin Vuln } & 0.000 & -0.002 & 0.001 & 0.258 & 0.328 & 0.336 & 0.138 & 0.148 & 0.149 \\
\hline & {$[0.005]$} & [0.004] & [0.003] & {$[0.279]$} & [0.331] & [0.310] & {$[0.097]$} & [0.104] & {$[0.103]$} \\
\hline Crisis $X$ IBrate $X$ Fin Vuln & $-0.009 * *$ & $-0.009 * *$ & $-0.009 * *$ & $0.471^{*}$ & $0.517^{* * *}$ & $0.599 * \star \star$ & 0.036 & 0.040 & 0.058 \\
\hline Factor endowments controls & Yes & Yes & Yes & Yes & Yes & Yes & Yes & Yes & Yes \\
\hline Initial size \& income controls & Yes & Yes & Yes & Yes & Yes & Yes & Yes & Yes & Yes \\
\hline Cty-Ind, Cty-Mth, Ind-Mth fixed effects & Yes & Yes & Yes & Yes & Yes & Yes & Yes & Yes & Yes \\
\hline Observations & 20,208 & 20,208 & 20,208 & 20,208 & 20,208 & 20,208 & 20,208 & 20,208 & 20,208 \\
\hline R-squared & 0.965 & 0.965 & 0.965 & 0.965 & 0.965 & 0.965 & 0.965 & 0.965 & 0.965 \\
\hline
\end{tabular}

Notes: See notes to Table 2. Standard errors are clustered by country, with ***, **, and * denoting significance at the $1 \%, 5 \%$, and $10 \%$ levels respectively. For each financial vulnerability measure, the first column dates the start of the crisis to March 2008, the second column uses the lag of the one-month IBrate, and the third column uses the three-month IBrate. All columns include the factor endowment controls, as well as the country size and income countrols. 
Table 5

Components of the Cost of Capital

\begin{tabular}{|c|c|c|c|c|c|c|}
\hline \multirow{3}{*}{$\begin{array}{l}\text { Crisis = 1: Sep } 08 \text { to Aug } 09 \\
\text { Fin Vulnerability measure: }\end{array}$} & \multicolumn{6}{|c|}{ Dependent variable: Log (Industry exports to the US) } \\
\hline & \multicolumn{2}{|c|}{ EXTFIN } & \multicolumn{2}{|c|}{ TCRED } & \multicolumn{2}{|c|}{ TANG } \\
\hline & (1) & (2) & (3) & (4) & (5) & (6) \\
\hline Cost of Capital measure: & TBill rate & IB spread & TBill rate & IB spread & TBill rate & IB spread \\
\hline \multirow[t]{2}{*}{ IB component $X$ Fin Vuln } & 0.003 & 0.008 & 0.036 & 0.068 & 0.038 & 1.176 \\
\hline & [0.004] & [0.007] & [0.100] & [0.145] & [0.408] & {$[0.819]$} \\
\hline \multirow[t]{2}{*}{ Crisis X IB component X Fin Vuln } & $-0.016^{*}$ & -0.010 & $0.161^{\star \star}$ & 0.124 & $0.919 * \star \star$ & 0.527 \\
\hline & [0.008] & [0.009] & {$[0.066]$} & [0.143] & {$[0.305]$} & [1.250] \\
\hline Factor endowments controls & Yes & Yes & Yes & Yes & Yes & Yes \\
\hline Initial size \& income controls & Yes & Yes & Yes & Yes & Yes & Yes \\
\hline Cty-Ind, Cty-Mth, Ind-Mth fixed effects & Yes & Yes & Yes & Yes & Yes & Yes \\
\hline Observations & 13,649 & 13,649 & 13,649 & 13,649 & 13,649 & 13,649 \\
\hline R-squared & 0.970 & 0.970 & 0.971 & 0.970 & 0.971 & 0.970 \\
\hline
\end{tabular}

Notes: See notes to Table 2. Standard errors are clustered by country, with ${ }^{* * *}$, **, and * denoting significance at the $1 \%, 5 \%$, and $10 \%$ levels respectively. For each financial vulnerability measure, the first column uses the 3-month local treasury bill rate as the cost of capital measure, while the second column uses the local IB spread (IBrate less the 3-month local treasury bill rate). All columns include the factor endowment controls, as well as the country size and income countrols.

Table 6

Effects on Trade vs. Production

\begin{tabular}{|c|c|c|c|c|c|c|}
\hline \multirow{3}{*}{$\begin{array}{l}\text { Crisis = 1: Sep } 08 \text { to Aug } 09 \\
\text { Fin Vulnerability measure: }\end{array}$} & \multicolumn{6}{|c|}{ Dependent variable: Log (Industry exports to the US) } \\
\hline & \multicolumn{2}{|c|}{ EXTFIN } & \multicolumn{2}{|c|}{ TCRED } & \multicolumn{2}{|c|}{ TANG } \\
\hline & (1) & (2) & (3) & (4) & (5) & (6) \\
\hline \multirow[t]{2}{*}{ IBrate X Fin Vuln } & -0.002 & -0.001 & -0.105 & -0.149 & 0.069 & 0.080 \\
\hline & [0.003] & [0.003] & [0.288] & {$[0.286]$} & [0.104] & [0.122] \\
\hline \multirow[t]{2}{*}{ Crisis X IBrate X Fin Vuln } & -0.007 & -0.006 & $0.557^{\star * *}$ & $0.706^{\star *}$ & $0.064^{\star \star}$ & 0.059 \\
\hline & [0.004] & [0.005] & [0.173] & [0.288] & {$[0.029]$} & {$[0.049]$} \\
\hline Factor endowments controls & No & Yes & No & Yes & No & Yes \\
\hline Initial size \& income controls & No & Yes & No & Yes & No & Yes \\
\hline IPI controls & Yes & Yes & Yes & Yes & Yes & Yes \\
\hline Cty-Ind, Cty-Mth, Ind-Mth fixed effects & Yes & Yes & Yes & Yes & Yes & Yes \\
\hline Observations & 17,695 & 15,758 & 17,695 & 15,758 & 17,695 & 15,758 \\
\hline R-squared & 0.963 & 0.965 & 0.963 & 0.965 & 0.963 & 0.965 \\
\hline
\end{tabular}

Notes: See notes to Table 2. Standard errors are clustered by country, with ${ }^{* * *}$, ${ }^{* *}$, and * denoting significance at the $1 \%, 5 \%$, and $10 \%$ levels respectively. For each financial vulnerability measure, the first column contains no auxillary controls, whereas the second column includes the factor endowment controls, and the country size and income controls. All columns control for Log(Industrial Production Index) $X$ Industry FEs and Crisis X Log(Industrial Production Index) X Industry FEs. 
Table 7

Final Goods Demand vs. Credit Supply Conditions in the Destination Market

\begin{tabular}{|c|c|c|c|c|c|c|c|c|c|}
\hline \multirow{3}{*}{$\begin{array}{l}\text { Crisis = 1: Sep } 08 \text { to Aug } 09 \\
\text { Fin Vulnerability measure: } \\
\text { Crisis measure: }\end{array}$} & \multicolumn{9}{|c|}{ Dependent variable: Log (Industry exports to the US) } \\
\hline & \multicolumn{3}{|c|}{ EXTFIN } & \multicolumn{3}{|c|}{ TCRED } & \multicolumn{3}{|c|}{ TANG } \\
\hline & $\begin{array}{c}(1) \\
\text { US retail }\end{array}$ & $\begin{array}{c}(2) \\
\text { US loans }\end{array}$ & $\begin{array}{c}(3) \\
\text { Joint Test }\end{array}$ & $\begin{array}{c}(4) \\
\text { US retail }\end{array}$ & $\begin{array}{c}(5) \\
\text { US loans }\end{array}$ & $\begin{array}{c}(6) \\
\text { Joint Test }\end{array}$ & $\begin{array}{c}(7) \\
\text { US retail }\end{array}$ & $\begin{array}{c}(8) \\
\text { US loans }\end{array}$ & $\begin{array}{c}\text { (9) } \\
\text { Joint Test }\end{array}$ \\
\hline IBrate X Fin Vuln & $\begin{array}{c}-1.439^{\star \star} \\
{[0.683]}\end{array}$ & $\begin{array}{l}0.143^{*} \\
{[0.072]}\end{array}$ & $\begin{array}{l}-1.203 \\
{[0.791]}\end{array}$ & $\begin{array}{l}73.515^{\star} \\
{[41.351]}\end{array}$ & $\begin{array}{c}-1.098 \\
{[1.733]}\end{array}$ & $\begin{array}{c}53.442 \\
{[62.033]}\end{array}$ & $\begin{array}{l}-1.258 \\
{[7.548]}\end{array}$ & $\begin{array}{c}-9.577 \\
{[12.211]}\end{array}$ & $\begin{array}{l}-4.802 \\
{[7.898]}\end{array}$ \\
\hline Log (US retail) X IBrate X Fin Vuln & $\begin{array}{l}0.073^{\star *} \\
{[0.035]}\end{array}$ & & $\begin{array}{c}0.066^{*} \\
{[0.038]}\end{array}$ & $\begin{array}{l}-3.726^{\star} \\
{[2.102]}\end{array}$ & & $\begin{array}{c}-3.081 \\
{[2.652]}\end{array}$ & $\begin{array}{c}0.073 \\
{[0.383]}\end{array}$ & & $\begin{array}{c}0.182 \\
{[0.376]}\end{array}$ \\
\hline Log (US loans) X IBrate X Fin Vuln & & $\begin{array}{c}-0.020 * \star \\
{[0.010]}\end{array}$ & $\begin{array}{c}-0.012 \\
{[0.010]}\end{array}$ & & $\begin{array}{c}0.173 \\
{[0.236]}\end{array}$ & $\begin{array}{c}1.024 \\
{[1.879]}\end{array}$ & & $\begin{array}{c}1.392 \\
{[1.692]}\end{array}$ & $\begin{array}{c}0.192 \\
{[0.240]}\end{array}$ \\
\hline Factor endowments controls & Yes & Yes & Yes & Yes & Yes & Yes & Yes & Yes & Yes \\
\hline Initial size \& income controls & Yes & Yes & Yes & Yes & Yes & Yes & Yes & Yes & Yes \\
\hline Cty-Ind, Cty-Mth, Ind-Mth fixed effects & Yes & Yes & Yes & Yes & Yes & Yes & Yes & Yes & Yes \\
\hline Observations & 20,208 & 20,208 & 20,208 & 20,208 & 20,208 & 20,208 & 20,208 & 20,208 & 20,208 \\
\hline R-squared & 0.965 & 0.965 & 0.965 & 0.965 & 0.965 & 0.965 & 0.965 & 0.965 & 0.965 \\
\hline
\end{tabular}

Notes: See notes to Table 2. Standard errors are clustered by country, with $* \star *$, **, and * denoting significance at the $1 \%, 5 \%$, and $10 \%$ levels respectively. For each financial vulnerability measure, the table explores how final demand proxied by Log (US retail sales) or credit supply proxied by Log (US business loans) interact with credit conditions in the exporting country and financial vulnerability of the industry in explaining exports to the US. All columns include the factor endowment controls, as well as the country size and income countrols. 
Table 8

Credit Conditions and Trade Volumes across Countries

\begin{tabular}{|c|c|c|c|c|c|}
\hline \multirow[t]{2}{*}{ Crisis = 1: Sep 08 to Aug 09} & \multicolumn{2}{|c|}{ Dependent variable: } & \multicolumn{3}{|c|}{ Log (Industry exports to the US) } \\
\hline & (1) & (2) & (3) & (4) & (5) \\
\hline \multirow[t]{2}{*}{ IBrate } & $-0.162^{*}$ & $-0.143^{\star}$ & $-0.199 *$ & -0.037 & 0.019 \\
\hline & {$[0.079]$} & {$[0.082]$} & [0.101] & {$[0.064]$} & [0.067] \\
\hline \multirow[t]{2}{*}{ Crisis X IBrate } & & -0.036 & $-0.069 * *$ & $-0.059 * *$ & -0.060 \\
\hline & & {$[0.167]$} & {$[0.030]$} & {$[0.026]$} & {$[0.037]$} \\
\hline Factor endowments controls & No & No & Yes & Yes & Yes \\
\hline Initial size \& income controls & No & No & No & Yes & Yes \\
\hline IPI controls & No & No & No & No & Yes \\
\hline Ind-Mth fixed effects & Yes & Yes & Yes & Yes & Yes \\
\hline Observations & 22,145 & 22,145 & 20,208 & 20,208 & 15,758 \\
\hline R-squared & 0.283 & 0.284 & 0.336 & 0.577 & 0.603 \\
\hline
\end{tabular}

Notes: Standard errors are clustered by country, with ${ }^{\star \star \star},{ }^{\star *}$, and ${ }^{*}$ denoting significance at the $1 \%, 5 \%$, and $10 \%$ levels respectively. The dependent variable is log monthly exports to the US in 3-digit NAICS manufacturing industries, covering Nov 06 to Oct 09. All specifications include industry-month fixed effects. The Crisis variable equals 1 from Sep 08 to Aug 09. All columns control for the log bilateral exchange rate $(E X C H)$ and $C$ risis $X$ $\log (E X C H)$. Columns (3)-(5) control for $\log (K / L)$, Crisis $X \log (K / L), \log (H / L)$, and Crisis X Log(H/L). Columns (4)-(5) control for $\log (G D P)$, Crisis $X \log (G D P)$, $\log (G D P p c)$, and Crisis $X \log (G D P p c)$. Column (5) further includes Log(Industrial Production Index) and Crisis X Log(Industrial Production Index). 
Table 9

Credit Conditions and Trade Volumes within Countries

\begin{tabular}{|c|c|c|c|}
\hline & $\begin{array}{l}\text { Dependent variable: } \\
\text { (1) }\end{array}$ & $\begin{array}{l}\log (\text { Indu } \\
\text { (2) }\end{array}$ & $\begin{array}{l}\text { s to the US) } \\
\text { (3) }\end{array}$ \\
\hline \multicolumn{4}{|l|}{ Nov 06 to Oct 09: } \\
\hline IBrate & $\begin{array}{l}0.016^{\star \star} \\
{[0.008]}\end{array}$ & $\begin{array}{l}0.016^{\star} \\
{[0.008]}\end{array}$ & $\begin{array}{c}0.008 \\
{[0.006]}\end{array}$ \\
\hline $\begin{array}{l}\text { Observations } \\
\text { R-squared }\end{array}$ & $\begin{array}{c}22,901 \\
0.961\end{array}$ & $\begin{array}{c}22,145 \\
0.961\end{array}$ & $\begin{array}{c}17,695 \\
0.960\end{array}$ \\
\hline \multicolumn{4}{|l|}{ Nov 06 to Aug 08: } \\
\hline IBrate & $\begin{array}{c}0.028^{*} \\
{[0.016]}\end{array}$ & $\begin{array}{c}0.023 \\
{[0.015]}\end{array}$ & $\begin{array}{c}0.003 \\
{[0.014]}\end{array}$ \\
\hline $\begin{array}{l}\text { Observations } \\
\text { R-squared }\end{array}$ & $\begin{array}{c}14,121 \\
0.966\end{array}$ & $\begin{array}{c}13,659 \\
0.966\end{array}$ & $\begin{array}{c}10,937 \\
0.964\end{array}$ \\
\hline \multicolumn{4}{|l|}{ Sep 08 to Dec 08: } \\
\hline IBrate & $\begin{array}{l}-0.025^{\star *} \\
{[0.010]}\end{array}$ & $\begin{array}{l}-0.022^{\star *} \\
{[0.009]}\end{array}$ & $\begin{array}{c}-0.033^{\star \star *} \\
{[0.009]}\end{array}$ \\
\hline $\begin{array}{l}\text { Observations } \\
\text { R-squared }\end{array}$ & $\begin{array}{l}2,566 \\
0.981\end{array}$ & $\begin{array}{l}2,482 \\
0.982\end{array}$ & $\begin{array}{l}1,988 \\
0.980\end{array}$ \\
\hline \multicolumn{4}{|l|}{ Jan 09 to Oct 09: } \\
\hline IBrate & $\begin{array}{c}0.016 \\
{[0.021]}\end{array}$ & $\begin{array}{c}0.009 \\
{[0.021]}\end{array}$ & $\begin{array}{c}0.012 \\
{[0.025]}\end{array}$ \\
\hline $\begin{array}{l}\text { Observations } \\
\text { R-squared }\end{array}$ & $\begin{array}{l}6,214 \\
0.968\end{array}$ & $\begin{array}{l}6,004 \\
0.969\end{array}$ & $\begin{array}{l}4,770 \\
0.969\end{array}$ \\
\hline $\begin{array}{l}\text { Log (Exchange Rate) } \\
\text { Log (IPI) } \\
\text { Cty-Ind, Ind-Mth fixed effects }\end{array}$ & $\begin{array}{l}\text { No } \\
\text { No } \\
\text { Yes }\end{array}$ & $\begin{array}{l}\text { Yes } \\
\text { No } \\
\text { Yes }\end{array}$ & $\begin{array}{l}\text { Yes } \\
\text { Yes } \\
\text { Yes }\end{array}$ \\
\hline
\end{tabular}

Notes: Standard errors are clustered by country, with ${ }^{* \star},{ }^{* *}$, and ${ }^{*}$ denoting significance at the $1 \%, 5 \%$, and $10 \%$ levels respectively. The dependent variable is log monthly exports to the US in 3-digit NAICS

manufacturing industries. All specifications include country-industry and industry-month fixed effects.

Regressions are performed in each panel for the months stated. Columns (2)-(3) control for Log(EXCH), while

Column (3) also controls for Log (Industrial Production Index). 
Appendix Table 1A

List of Countries with Interbank Rate Data (Datastream)

Australia (AUS); Belgium (BEL); Bulgaria (BGR); Canada (CAN); China (CHN);

Czech Republic (CZE); Germany (DEU); Denmark (DNK); Spain (ESP); Finland (FIN);

France (FRA); Great Britain (GBR); Greece (GRC); Hong Kong (HKG); Hungary (HUN);

Ireland (IRL); Italy (ITA); Japan (JPN); Malaysia (MYS); Netherlands (NLD); Norway (NOR);

New Zealand (NZL); Poland (POL); Portugal (PRT); Romania (ROM); Singapore (SGP);

Slovakia (SVK); Sweden (SWE); Thailand (THA); Turkey (TUR); Taiwan (TWN)

Notes: Sample consists of 31 countries for which one-month interbank rate data was available from Thomson Datastream.

Appendix Table 1B

Summary Statistics for Country One-Month Interbank Rates

\begin{tabular}{c|ccccccc}
\hline \hline & Min & 5 pct & Median & 95th pct & Max & Mean & Std Dev \\
\hline \hline Nov 06 & 0.38 & 1.67 & 3.47 & 8.76 & 19.26 & 4.52 & 3.23 \\
Mar 08 & 0.85 & 1.22 & 4.31 & 10.27 & 16.35 & 4.97 & 2.92 \\
Sep 08 & 0.74 & 1.28 & 4.66 & 12.99 & 18.12 & 5.32 & 3.30 \\
Jan 09 & 0.25 & 0.50 & 2.16 & 14.59 & 15.14 & 3.52 & 3.61 \\
Oct 09 & 0.12 & 0.15 & 0.44 & 7.38 & 10.33 & 1.77 & 2.47 \\
\hline \hline
\end{tabular}


Appendix Table 2

Industry Characteristics: Summary Statistics

\begin{tabular}{|c|c|c|c|c|c|c|}
\hline NAICS & Industry & $\begin{array}{c}\text { External } \\
\text { Finance Dep } \\
\text { (EXTFIN) }\end{array}$ & $\begin{array}{c}\text { Asset } \\
\text { Tangibility } \\
\text { (TANG) }\end{array}$ & $\begin{array}{c}\text { Trade Credit } \\
\text { (TCRED) }\end{array}$ & $\begin{array}{l}\text { Phy Cap } \\
\text { Intensity } \\
(\log (k / l))\end{array}$ & $\begin{array}{c}\text { Human Cap } \\
\text { Intensity } \\
(\log (h / l))\end{array}$ \\
\hline 311 & Food Manufacturing & -0.558 & 0.332 & 0.078 & 4.854 & -1.424 \\
\hline 312 & Beverage and Tobacco Product Manufacturing & -0.452 & 0.321 & 0.044 & 5.132 & -0.918 \\
\hline 313 & Textile Mills & -0.154 & 0.371 & 0.063 & 4.198 & -1.893 \\
\hline 314 & Textile Product Mills & -0.335 & 0.264 & 0.024 & 3.313 & -1.671 \\
\hline 315 & Apparel Manufacturing & -0.646 & 0.131 & 0.066 & 2.617 & -1.943 \\
\hline 316 & Leather and Allied Product Manufacturing & -1.857 & 0.115 & 0.083 & 3.254 & -1.853 \\
\hline 321 & Wood Product Manufacturing & -0.372 & 0.428 & 0.037 & 3.816 & -1.820 \\
\hline 322 & Paper Manufacturing & -0.366 & 0.535 & 0.063 & 5.783 & -1.459 \\
\hline 323 & Printing and Related Support Activities & -0.487 & 0.296 & 0.084 & 3.587 & -0.628 \\
\hline 324 & Petroleum and Coal Products Manufacturing & -0.175 & 0.551 & 0.123 & 6.857 & -1.040 \\
\hline 325 & Chemical Manufacturing & 5.472 & 0.138 & 0.032 & 5.606 & -0.848 \\
\hline 326 & Plastics and Rubber Products Manufacturing & -0.278 & 0.355 & 0.081 & 4.280 & -1.571 \\
\hline 327 & Nonmetallic Mineral Product Manufacturing & -0.394 & 0.417 & 0.050 & 4.403 & -1.562 \\
\hline 331 & Primary Metal Manufacturing & -0.364 & 0.406 & 0.084 & 5.584 & -1.407 \\
\hline 332 & Fabricated Metal Product Manufacturing & -0.781 & 0.279 & 0.093 & 4.097 & -1.391 \\
\hline 333 & Machinery Manufacturing & -0.237 & 0.182 & 0.070 & 4.380 & -1.001 \\
\hline 334 & Computer and Electronic Product Manufacturing & 0.435 & 0.116 & 0.054 & 4.686 & -0.726 \\
\hline 335 & Electrical Equipment, Appliance, and Component Manufacturing & -0.288 & 0.197 & 0.080 & 3.973 & -1.297 \\
\hline 336 & Transportation Equipment Manufacturing & -0.386 & 0.250 & 0.120 & 4.957 & -1.643 \\
\hline 337 & Furniture and Related Product Manufacturing & -1.040 & 0.289 & 0.081 & 2.952 & -1.387 \\
\hline 339 & Miscellaneous Manufacturing & 0.549 & 0.135 & 0.042 & 3.597 & -1.227 \\
\hline
\end{tabular}

Notes: EXTFIN, TANG and TCRED are calculated from 1996-2005 Compustat data. Log(k/l) and Log(h/l) are calculated from 1996 NBER-CES data for US manufacturing. For more details, please see the Data Appendix. 


\section{Appendix Table 3}

Effects of the Crisis on Trade across Countries and Sectors: Joint Tests

\begin{tabular}{|c|c|c|c|}
\hline$\underline{\text { Crisis }=1: \text { Sep } 08 \text { to Aug } 09}$ & $\begin{array}{l}\text { Dependent variable: } \\
\text { (1) }\end{array}$ & $\begin{array}{l}\log \text { (Indu } \\
\quad(2)\end{array}$ & $\begin{array}{l}\text { to the US) } \\
\text { (3) }\end{array}$ \\
\hline IBrate X EXTFIN & $\begin{array}{c}0.003 \\
{[0.006]}\end{array}$ & $\begin{array}{c}0.006 \\
{[0.008]}\end{array}$ & $\begin{array}{l}-0.001 \\
{[0.007]}\end{array}$ \\
\hline Crisis X IBrate X EXTFIN & $\begin{array}{l}-0.003 \\
{[0.005]}\end{array}$ & $\begin{array}{c}-0.004 \\
{[0.005]}\end{array}$ & $\begin{array}{c}0.001 \\
{[0.007]}\end{array}$ \\
\hline IBrate $X$ TCRED & $\begin{array}{c}0.261 \\
{[0.346]}\end{array}$ & $\begin{array}{c}0.305 \\
{[0.388]}\end{array}$ & $\begin{array}{l}-0.244 \\
{[0.327]}\end{array}$ \\
\hline Crisis $X$ IBrate $X$ TCRED & $\begin{array}{l}0.394^{* *} \\
{[0.180]}\end{array}$ & $\begin{array}{c}0.464^{*} \\
{[0.243]}\end{array}$ & $\begin{array}{c}0.692^{*} \\
{[0.367]}\end{array}$ \\
\hline IBrate X TANG & $\begin{array}{c}0.122 \\
{[0.098]}\end{array}$ & $\begin{array}{c}0.146 \\
{[0.116]}\end{array}$ & $\begin{array}{c}0.083 \\
{[0.131]}\end{array}$ \\
\hline Crisis $X$ IBrate $X$ TANG & $\begin{array}{c}0.035^{\star} \\
{[0.017]}\end{array}$ & $\begin{array}{c}0.026 \\
{[0.046]}\end{array}$ & $\begin{array}{c}0.039 \\
{[0.052]}\end{array}$ \\
\hline $\begin{array}{l}\text { Factor endowments controls } \\
\text { Initial size \& income controls } \\
\text { IPI controls } \\
\text { Cty-Ind, Cty-Mth, Ind-Mth fixed effects }\end{array}$ & $\begin{array}{l}\text { No } \\
\text { No } \\
\text { No } \\
\text { Yes }\end{array}$ & $\begin{array}{l}\text { Yes } \\
\text { Yes } \\
\text { No } \\
\text { Yes }\end{array}$ & $\begin{array}{l}\text { Yes } \\
\text { Yes } \\
\text { Yes } \\
\text { Yes }\end{array}$ \\
\hline $\begin{array}{l}\text { Observations } \\
\text { R-squared }\end{array}$ & $\begin{array}{c}22,901 \\
0.964\end{array}$ & $\begin{array}{c}20,208 \\
0.965\end{array}$ & $\begin{array}{c}15,758 \\
0.965\end{array}$ \\
\hline
\end{tabular}

Notes: See notes to Table 2 . Standard errors are clustered by country, with $* * *, * *$, and $*$ denoting significance at the $1 \%$, $5 \%$, and $10 \%$ levels respectively. Column (1) is a lean specification containing no auxillary controls. Column (2) includes the factor endowment controls, and the country size and income controls. Column (3) additionally controls for Log(Industrial Production Index) X Industry FEs and Crisis X Log(Industrial Production Index) X Industry FEs. 
Figure 1

The Decline in US Trade Volumes during the Global Financial Crisis

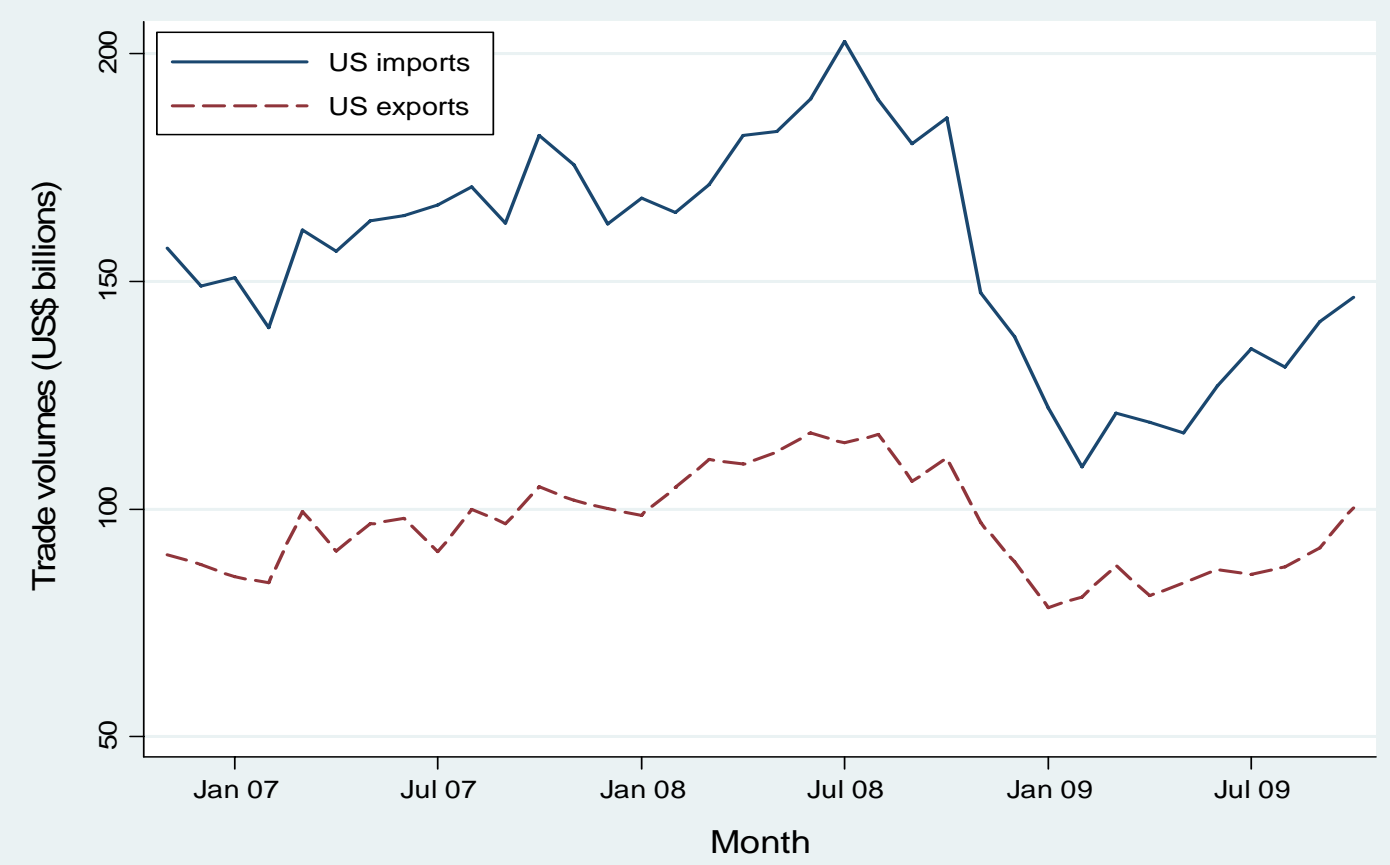

Source: US Census Bureau.

Figure 2

Interbank Rates during the Global Financial Crisis

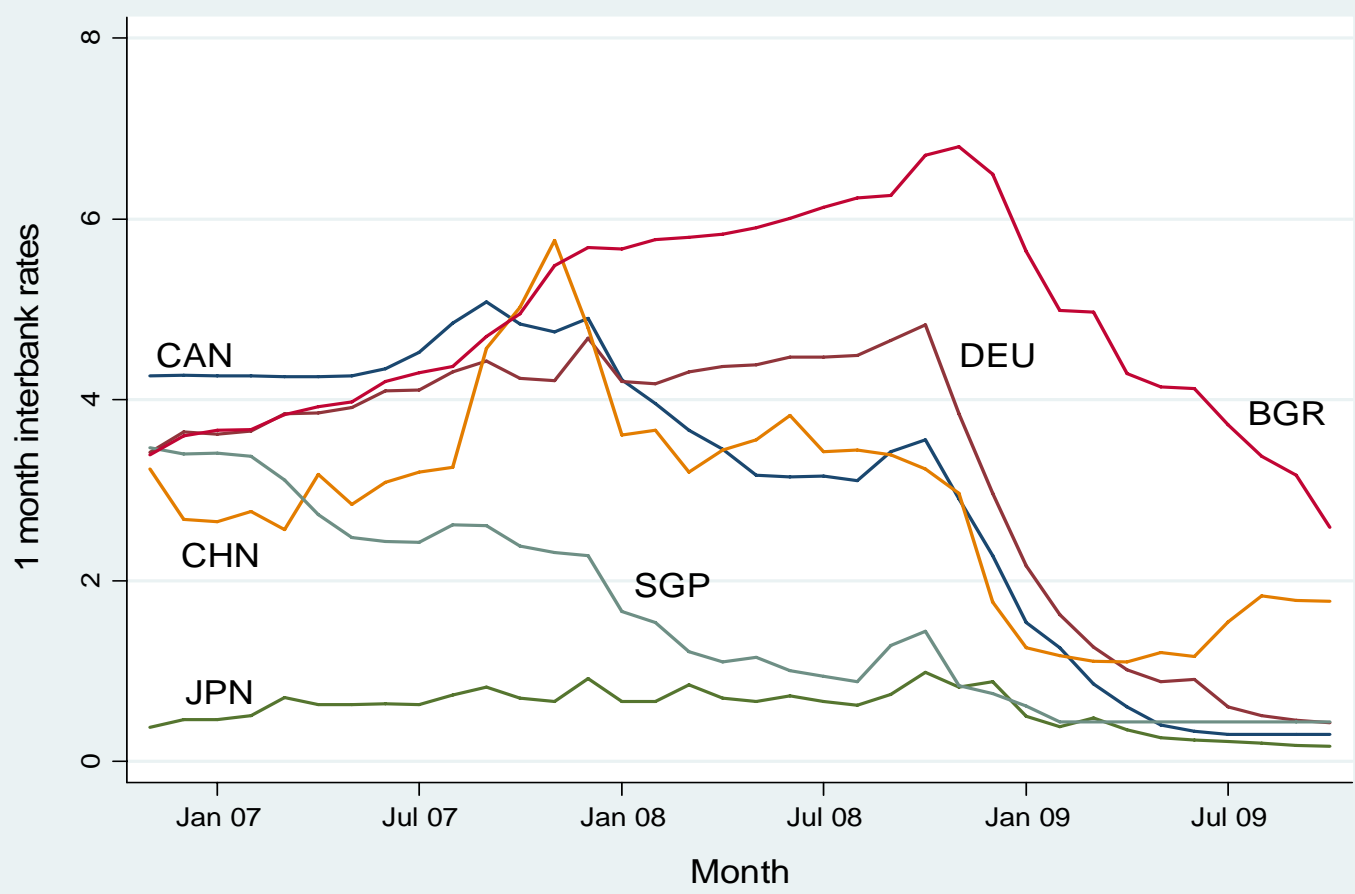

Source: Thomson Datastream. 
Figure 3

The Importance of Credit Channels of Comparative Advantage over Time

\section{A: IBrate X EXTFIN}

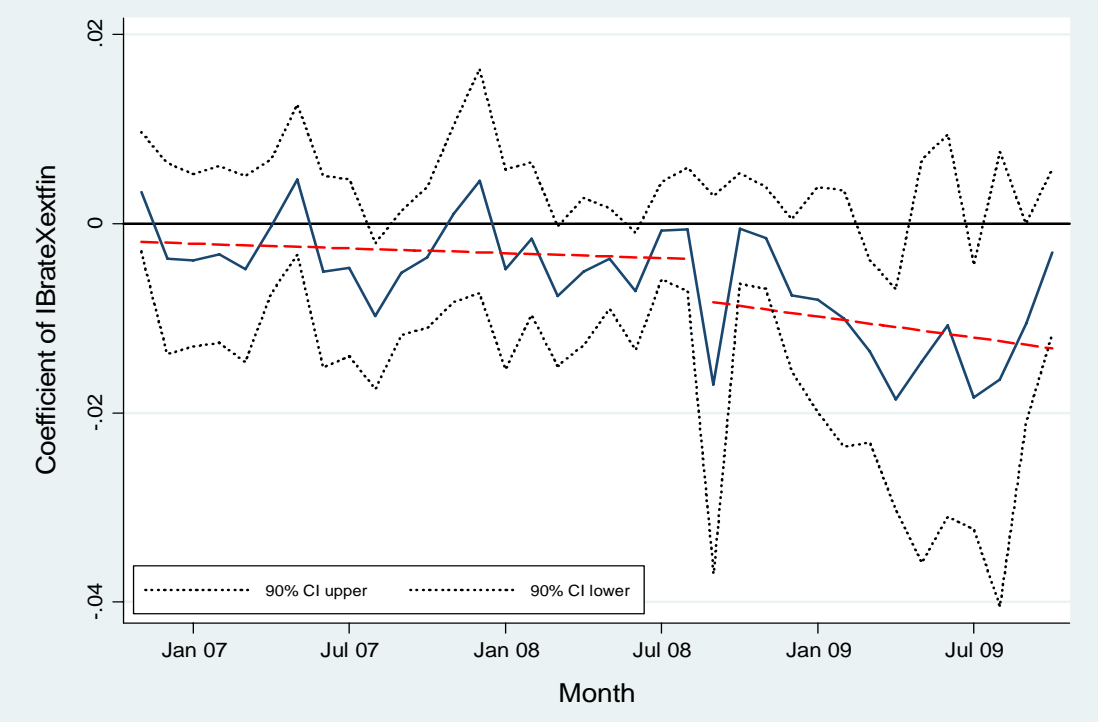

\section{B: IBrate X TCREDIT}

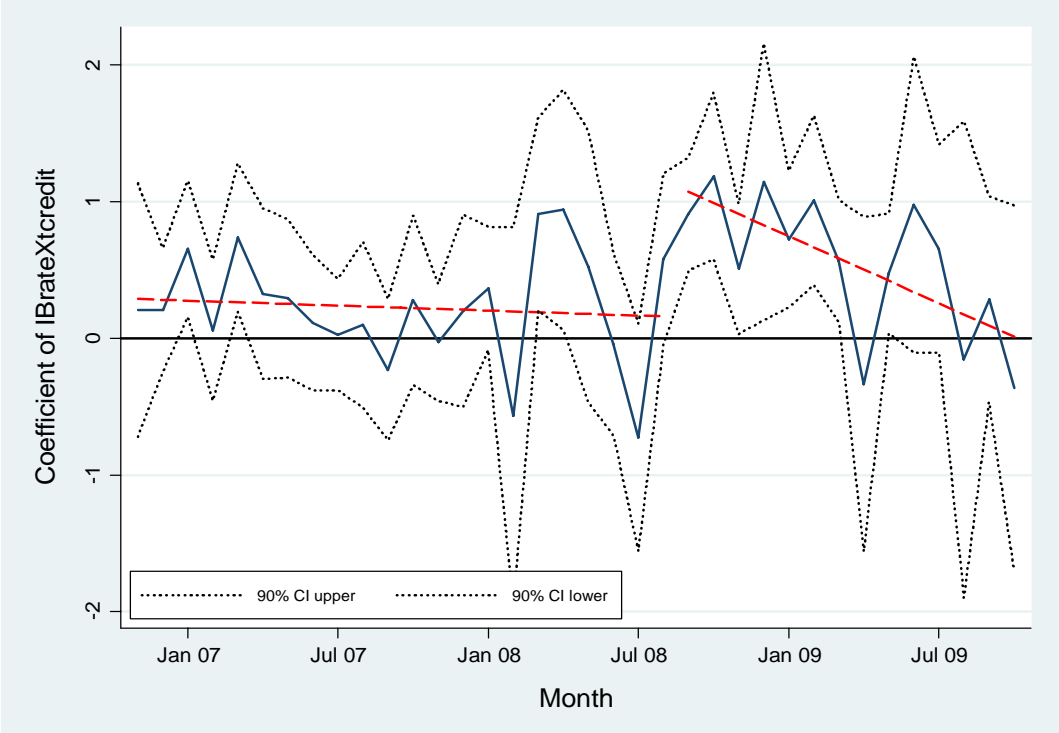

\section{C: IBrate X TANG}

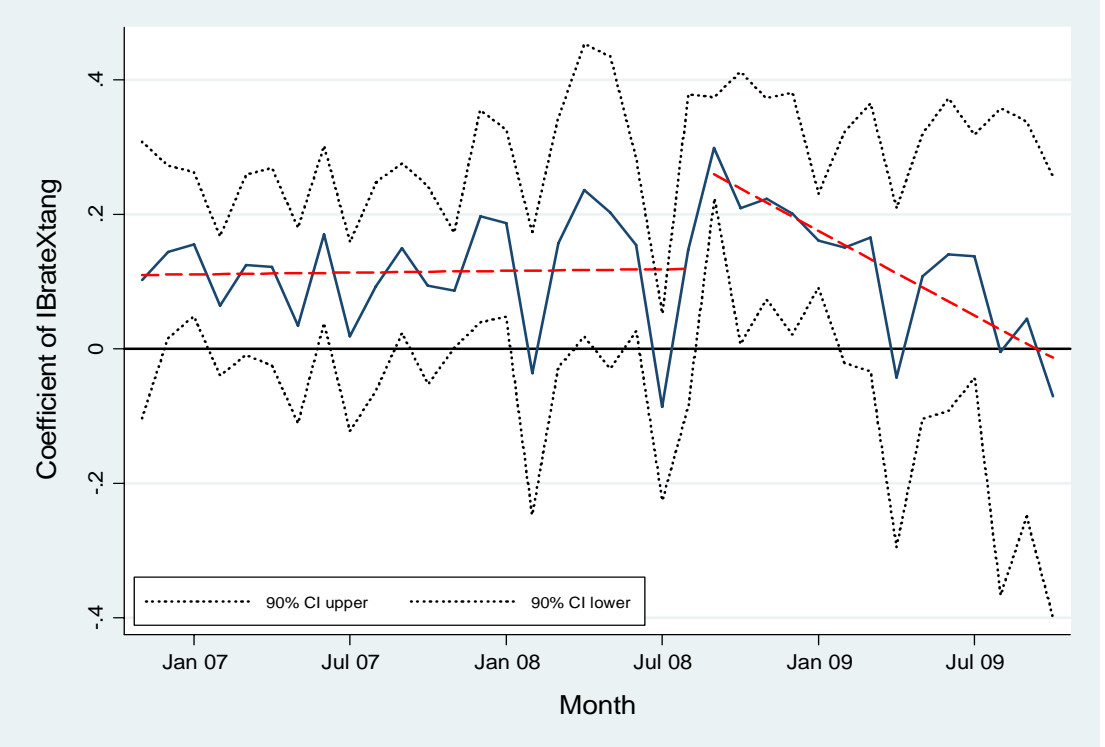

Notes: The month-varying $\beta_{m}$ coefficients of IBrate X Fin Vuln are obtained by estimating equation (2), as described in Section 5.3. The Fin Vuln measure in Panel A is EXTFIN, while that used in Panels B and C are TCREDIT and TANG respectively. In each panel, the dotted lines indicate the bounds of the $90 \%$ confidence interval of each $\beta_{m}$ coefficient. Two linear trend lines for the $\beta_{m}$ 's are plotted, one for pre-September 2008 and a second for September 2008 and after. A horizontal line at 0 is included. 